\title{
The Politics of Administrative Law: New York's Anti-Bureaucracy Clause and the O'Brian-Wagner Campaign of 1938
}

Daniel R. Ernst

Georgetown University Law Center, ernst@law.georgetown.edu

Copyright @ 2009 Cambridge University Press; http://journals.cambridge.org/action/ displayJournal?jid=LHR

This paper can be downloaded free of charge from:

https://scholarship.law.georgetown.edu/facpub/576

27 Law \& Hist. Rev. 331-372 (2009)

This open-access article is brought to you by the Georgetown Law Library. Posted with permission of the author. Follow this and additional works at: https://scholarship.law.georgetown.edu/facpub

Part of the Administrative Law Commons, Law and Politics Commons, and the Legal History Commons 


\section{The Politics of Administrative Law: New York's Anti-Bureaucracy Clause and the O'Brian-Wagner Campaign of 1938}

\section{DANIEL R. ERNST}

In April 1938 New York's first constitutional convention since 1915 convened in Albany. When it adjourned in late August, one of the amendments slated for a referendum that fall was an "anti-bureaucracy clause," a provision that would greatly increase the New York courts' oversight of the state's agencies. Although voters rejected it, contemporaries saw the anti-bureaucracy clause as a harbinger of a national campaign against the New Deal. In September 1938 Charles Wyzanski, a former member of the Solicitor General's office, warned Attorney General Homer Cummings that the anti-bureaucracy clause was "the advance signal of an approaching partisan attack on a national scale." Wyzanski was right: in early 1939 a bill endorsed by the American Bar Association's House of Delegates was introduced in Congress by Representative Francis Walter and Senator Marvel Mills Logan. ${ }^{1}$ Just as the New York provision "would have almost certainly

1. Charles E. Wyzanski to Homer S. Cummings, September 29, 1938, box 75, Homer Stille Cummings Papers, University of Virginia, Charlottesville, Va. On the Walter-Logan bill,

Daniel R. Ernst is a professor of law at the Georgetown University Law Center <ernst@law.georgetown.edu>. He wishes to thank Karen L. Spencer and David Warrington for help with manuscript collections in their respective libraries; Jill Elaine Hasday and Daniel J. Gifford for their remarks at the Minnesota Public Law Workshop; Laura Kalman, Fred Konefsky, and John Henry Schlegel for their comments; and Alexis K. Paddock for her research assistance. He presented a version of this article at "A Conference in Honor of Stanley Katz: Teacher, Scholar, Citizen." The article was inspired by Katz's essay, "The Politics of Law in Colonial America: Controversies over Chancery Courts and Equity Law in the Eighteenth Century," Perspectives in American History 5 (1971): 485-518. 
destroyed the effectiveness of the state administrative agencies," the New Dealer Abe Feller warned Cummings's successor, so would the WalterLogan bill hamstring the federal government. ${ }^{2}$ When President Franklin Roosevelt vetoed the bill in December 1940, he declared it part of a national campaign that had begun with the anti-bureaucracy clause. ${ }^{3}$

Soon after New York's constitutional convention adjourned, the state parties held their conventions. New York's Democrats nominated Robert F. Wagner to another term in the U.S. Senate; to face him Republicans unexpectedly selected John Lord O'Brian, a Buffalo lawyer who had served as U.S. attorney and assistant attorney general under Theodore Roosevelt, Woodrow Wilson, and Herbert Hoover. When nominated, O'Brian was in Chattanooga preparing to defend the Tennessee Valley Authority (TVA) before the U.S. Supreme Court. O'Brian did not unseat Wagner, but his attacks on the senator's legislative offspring, the National Labor Relations Board (NLRB), won him the support of New York City's civic elite and the endorsement of the New York Times, which had previously backed Democratic senatorial candidates. Even President Roosevelt was alarmed. In the last days of the campaign, he summoned the NLRB's members to the White House to ask them to change their procedures and "help Bob Wagner get re-elected."4

Historians have interpreted controversies over administrative law in the late New Deal as a clash of interests or ideas. The claim that business interests sought to strengthen judicial review of New Deal agencies is as old as the New Deal itself. In passing the Walter-Logan bill or voting for an investigation of the NLRB's procedures, a conservative coalition in Congress was doing Big Business's bidding; so were the lawyers who drafted the bill and challenged the NLRB in the courts. ${ }^{5}$ Other historians have put ideas before interests in their accounts. New Dealers embraced "the virtues of "expertness"" and of "prescriptive government"; as "modernists" and "pragmatists," they argued that administrators should wield legislative, executive, and judicial power, be free from the dead hand of precedents

see George B. Shepherd, "Fierce Compromise: The Administrative Procedure Act Emerges from New Deal Politics," Northwestern University Law Review 90 (1996): 1593-1632.

2. Abe Feller to Frank Murphy, January 19, 1939, box 4401, entry 112, Records of the

U.S. Department of Justice, Record Group 60, National Archives II (RG 60).

3. Congressional Record, 76th Cong., 3d sess., 1941, 13942-43.

4. J. Warren Madden, interview by Judith Byne Seidman, October 29, 1968, 40, NLRB Oral History Project, Kheel Center for Labor-Management Documentation and Archives, Martin P. Catherwood Library, School of Industrial and Labor Relations, Cornell University, Ithaca, N.Y. (Madden, Cornell Interview).

5. Wyzanski to Cummings; A. H. Feller, "Administrative Justice," Survey Graphic 27 (1938): 494; Shepherd, "Fierce Compromise"; James E. Brazier, "An Anti-New Dealer Legacy: The Administrative Procedure Act," Journal of Policy History 8 (1996): 206-26. 
and the trammels of adversarial procedure, and exercise their "discretion, informed by expertise."6 The New Dealers" opponents were "legalists" and objected to the New Deal on "orthodox constitutional" grounds. They considered autonomous bureaucracies and discretion-wielding administrators to be the very antithesis of the rule of law. ${ }^{7}$

Under either account, the controversies over administrative procedure in New York in 1938 are puzzling anomalies. No lawyer was more prominently associated with the New Deal than the Harvard professor Felix Frankfurter or more frequently named among the New Deal's opponents than the Sullivan \& Cromwell lawyer John Foster Dulles, yet they fought the anti-bureaucracy clause as members of the same committee, appointed by the great corporation lawyer Henry Stimson, a cabinet member in two Republican administrations. In 1938 no New Deal agencies were under fiercer attack than the TVA and NLRB. If corporate clients or a commitment to "legalism" determined a lawyer's stand on the administrative state, how could O'Brian have led the constitutional defense of the TVA in September, suspended his efforts to campaign against the NLRB's creator in October, and resumed his championing of the TVA in November?

Interests and ideas alone cannot identify the shared premises of Frankfurter and Dulles or the consistent path O'Brian followed in defending the TVA and attacking the NLRB. Two institutions, the political party and the legal profession, must also be considered. The emergence of the administrative state created divisions within each institution. First, the major political parties split into "regular" and "liberal" factions over the prospect that chief executives could use agencies to reward friends and punish enemies without consulting party chieftains in state legislatures and Congress. Second, the majority of American lawyers who still practiced in and before courts regarded the informal procedures of agencies and discretion of administrators as threats to their expertise and livelihood. Increasingly after 1900, however, corporation lawyers in the great "law factories" of New York defended administration because they preferred negotiating with knowledgeable administrators to parrying the unpredictable, partisan thrusts of legislators or litigating before an unspecialized, "generalist" bench.

6. Morton J. Horwitz, The Transformation of American Law, 1870-1960: The Crisis of Legal Orthodoxy (New York: Oxford University Press, 1992), 216, 221; G. Edward White, The Constitution and the New Deal (Cambridge, Mass.: Harvard University Press, 2000), 114-16; Reuel E. Schiller, "The Era of Deference: Courts, Expertise, and the Emergence of New Deal Administrative Law," Michigan Law Review 106 (2007): 406, 413-14; Jessica Wang, "Imagining the Administrative State: Legal Pragmatism, Securities Regulation, and New Deal Liberalism," Journal of Policy History 17 (2005): 257-93.

7. Horwitz, Transformation, 225-30; White, Constitution and the New Deal, 96-103. 
The autonomous role of the political party and legal profession in the politics of administrative law explains the peculiar way in which administrative agencies were incorporated into the American polity. Business interests sought intrusive judicial review of agencies' findings of fact and interpretation of law, which had already turned rate making by public utility commissions into "a failure, if not a farce." review of agencies' actions by common-law judges to be the very definition of the rule of law, a position we can call "institutional Diceyism," after the influential formulation of the English jurist Albert Venn Dicey. ${ }^{9}$ Both had to settle for something less, a procedural version of Dicey's rule of law. As long as an agency's proceedings mimicked judicial procedures, regulated concerns would have to settle for a "day in commission." They usually could not get a further "day in court." 10

The controversy over administrative law in New York in 1938 was a decisive moment in the emergence of procedural Diceyism in the United States. On a stage crowded with partisan and legal performers, the politics of administrative law played out in two acts. In the first, the state's trial lawyers mounted a campaign to heighten judicial review of the state's administrative agencies. Their efforts culminated in the adoption of the anti-bureaucracy clause at the state constitutional convention when regular factions in the state's two major parties decided it would serve their purposes. New Yorkers rejected the measure after liberal politicians and corporation lawyers cast it as a cynical attempt to hamstring indispensable bureaucracies. The defeat of the anti-bureaucracy clause revealed a lack of popular support for institutional Diceyism, but it was no mandate for administrators to do as they pleased. A second act, the O'Brian-Wagner senatorial race, became a referendum on the partisan use of bureaucracy after O'Brian attacked the NLRB for its structural and procedural irregularities and called for the judicialization of administrative procedure. His surprisingly strong showing made clear the political appeal of procedural Diceyism well before it became federal policy after World War II.

8. Charles E. Clark to Benjamin V. Cohen, December 28, 1936, box 7, Benjamin V. Cohen Papers, Library of Congress; see Morton Keller, Regulating a New Economy: Public Policy and Economic Change in America, 1900-1933 (Cambridge, Mass.: Harvard University Press, 1990), 62-65.

9. Albert Venn Dicey, Introduction to the Study of the Law of the Constitution, 8th ed. (1885; London: Macmillan, 1902), 182-83; see Horwitz, Transformation, 225.

10. John J. Burns to Dean Acheson, April 16, 1940, box 2, Dean G. Acheson Papers, Harry S Truman Library, Independence, Mo.; Walter Gellhorn, "Symposium on Procedural Administrative Law," Iowa Law Review 25 (1940): 421-23. 


\section{Dramatis Personae}

By 1938 the statebuilding of the New Deal had presented New York's traditional politicians with an unhappy prospect. Urban professionals and others who wore their partisan affiliations lightly threatened to use administrative agencies as the basis for new, executive-directed parties that could circumvent party bosses' control of legislatures and distribution of patronage. In the 1920s, Old Guard Republicans had contained an earlier burst of administrative statebuilding with patronage appointments and strict judicial review, and "the grand old boys of the Party" got their due after the Democrats regained the White House in 1933. ${ }^{11}$ In Roosevelt's second term, however, issue-oriented professionals in the administration, for whom the term "New Dealers" came to be reserved, plotted to remake the Democratic Party by centering it on the presidency, mobilizing voters with administratively implemented programs, and realigning Republicans and Democrats into "conservative" and "liberal" camps. Every favorable NLRB ruling, federal loan, radio license, and social security check was a link between the state and the citizenry, and each recipient was a potential member of a liberal political camp. Thus, as Martin Shefter has observed, the new bureaucracies promised to "perform for the administration precisely those functions served by party organizations in cities and states governed by centralized political machines." 12

A series of dramatic events convinced many observers that Roosevelt had signed onto the New Dealers' project. Roosevelt's executive reorganization and Court-packing plans of 1937 seemed calculated to strengthen his hand against rival branches of government; the attempted "purge" of anti-administration Democrats looked like a bid to become the master of the Democratic Party. NLRB rulings favoring the affiliates of the Congress of Industrial Organizations (CIO) looked like the quid pro quo for the CIO's $\$ 470,000$ contribution to his reelection campaign in 1936. A newspaper expose and congressional investigation of the partisan use of Works Progress Administration (WPA) funds unfolded over the summer of 1938. Although Roosevelt's actual intentions remain obscure, such developments were enough to drive

11. Stephen Skowronek, Building a New American State: The Expansion of National Administrative Capacities, 1877-1920 (New York: Cambridge University Press, 1982); G. Cullom Davis, "The Transformation of the Federal Trade Commission, 1914-1929," Mississippi Valley Historical Review 49 (1962): 437-55; [John Carter Franklin], The New Dealers (New York: Literary Guild, 1934), 270.

12. David Plotke, Building a Democratic Order: Reshaping American Liberalism in the 1930s and 1940s (New York: Cambridge University Press, 1996), 157; Martin Shefter, Political Parties and the State (Princeton, N.J.: Princeton University Press, 1994), 82-83. 
regular Democrats in Congress into a coalition with Republicans to block further New Deal legislation and to investigate the NLRB. ${ }^{13}$

With a former governor in the White House, New York's political affairs were thoroughly enmeshed in national politics. Five factions operated under the banners of three different political parties. One group of Democrats coalesced around the state's "little New Deal," presided over by Governor Herbert Lehman. It included financial regulation of public utilities, support for municipal power plants, unemployment insurance, an improved worker's compensation law, a minimum wage for women, an ambitious program of public housing, and a state labor relations board.${ }^{14}$ Conservative Democrats, led by Alfred E. Smith, resisted the New Dealers, who denied them patronage and plotted to weaken them through reapportionment. ${ }^{15}$ The leader of Smith's faction in Albany was Robert Whalen, a lawyer who looked upon the New Deal as a species of mob rule. ${ }^{16}$

The Republicans were also divided. The Old Guard, a conservative alliance of upstate farming and business interests, had strenuously opposed New York's little New Deal and wanted to "stand pat" until the Roosevelt recession of 1937-38 returned them to power. Their leader in the state senate was George Fearon, a hard-boiled lawyer from Syracuse. ${ }^{17}$ Since early 1938 they had lost ground within the party to a growing contingent of urban liberals, who accepted the basic policies of the New Deal. In New York City, they drew heavily from the civic elite, including great corporation lawyers like Herbert Hoover's Treasury Undersecretary Arthur Ballantine and Hoover's two solicitors general, Charles Evans Hughes, Jr., and Thomas Thacher. Liberal Republicans in the state legislature joined with Democrats to pass many of Lehman's measures; they worked to elect Fiorello La Guardia mayor of New York; they blocked Fearon's nomination for governor in 1936; and they outraged the Old Guard by joining in a fusion ticket with the American Labor Party (ALP) in 1937.18

13. Jason Scott Smith, Building New Deal Liberalism: The Political Economy of Public Works, 1933-1956 (New York: Cambridge University Press, 2006), 160-78; James T. Patterson, Congressional Conservatism and the New Deal: The Growth of the Conservative Coalition in Congress, 1933-1939 (Lexington: University of Kentucky Press, 1967), 2.

14. Wilbert Losson Hindman, Jr., "The New York Constitutional Convention of 1938: The Constituent Process and Interest Activity" (Ph.D. diss., University of Michigan, 1940), 18; Robert P. Ingalls, Herbert H. Lehman and New York's Little New Deal (New York: New York University Press, 1975).

15. Judith Stein, "The Birth of Liberal Republicanism in New York State, 1932-1939" (Ph.D. diss., Yale University, 1968), 19-21.

16. "Robert E. Whalen, Albany Attorney," New York Times, August 13, 1951, 17 (NYT); "Ochlocracy Here Is Feared," ibid., November 7, 1941, 22.

17. Ingalls, Lehman, 88, 254; Hindman, "Constitutional Convention," 18; "Job No. 2," Time, September 5, 1932.

18. Stein, "Birth of Liberal Republicanism," 176-78; Ingalls, Lehman, 88, 254; Hindman, "Constitutional Convention," 19. 
That party was the fifth political force in the events of 1938. It had been organized in 1936 to give trade unionists, socialists, Republican fusionists, and independents a chance to support Roosevelt without having to back Tammany Democrats. The leaders of CIO affiliates, such as Sidney Hillman of the Amalgamated Clothing Workers of America and David Dubinsky of the International Ladies' Garment Workers Union, dominated the ALP at its founding, but room was also made for George Meany, president of the New York State Federation of Labor, and for several American Federation of Labor (AFL) affiliates. The ALP turned out almost 275,000 votes for Roosevelt in 1936 and helped elect Liberal Republicans under the fusion agreement of 1937, but it suffered grievously when Meany led AFL affiliates out of the party in the spring of 1938 as part of a nationwide split between craft and industrial unionists. The ALP would give Lehman and Wagner their margins of victory later that year but more as the tail to a Democratic kite than as an independent labor party. ${ }^{19}$

In this political context, the anti-bureaucracy clause reenforced the tendency of New York's political groups to divide into anti- and pro-New Deal camps. Both Conservative Democrats and Old Guard Republicans saw it as a chance to savage the New Dealers for their alien, oppressive bureaucracies. New Deal Democrats, Liberal Republicans, and Laborites countered that the clause would paralyze the administrative measures that all modern societies needed. But if Liberal Republicans like Congressman Bruce Barton accepted collective bargaining and social security as "part of our American scheme of things," they refused to merge with the Democrats into a larger New Deal party. "The next national campaign will not be fought by a liberal party and a reactionary party," Barton declared in 1938. "The next campaign will be between a Republican liberal party and a Democratic radical party." ${ }^{20}$

New York's lawyers also had a stake in the controversies of 1938. Most of the state's lawyers were sole practitioners or members of small partnerships and represented private individuals in local courts. ${ }^{21}$ They regarded

19. Sheila Stern, "The American Labor Party, 1936-1944" (master's thesis, University of Chicago, 1964), 32-35, 63-64; Robert Frederick Carter, "Pressure from the Left: The American Labor Party, 1936-1954" (Ph.D. diss., Syracuse University, 1965), 8-17, 93-96; Warren Moscow, Politics in the Empire State (New York: Alfred A. Knopf, 1948), 105-08; Jin Hee Kim, "Labor Law and Labor Policy in New York State, 1920s-1930s" (Ph.D. diss., Binghamton University-State University of New York, 1999), 264-67.

20. Barton quoted in Stein, "Birth of Liberal Republicans," 205.

21. In New York County, where most of the state's large firms were located, 55 percent of all lawyers practiced individually in 1934. A national estimate in 1948 found that 61 percent of American lawyers practiced individually. Committee on Professional Economics of the New York County Lawyers' Association, Survey of the Legal Profession in New York County (New York, 1936), 11-12; Fred B. Weil, ed., The 1967 Lawyer Statistical Report (Chicago: American Bar Foundation, 1968), 18. 
administrative hearings as, at best, second-rate imitations of judicial trials and at worst travesties in which lay officials ignored the law of evidence and freely engaged in ex parte contacts. Many trial lawyers were active in their local political parties; they dominated the New York State Bar Association (NYSBA); and they must have accounted for most of the 120 lawyers among the 168 delegates at the constitutional convention of $1938 .{ }^{22}$

A very different bar had emerged in New York City after the Civil War when a cohort of lawyers discovered that incorporations, securities, mergers, and reorganizations were far more lucrative than courtroom advocacy. Around 1900, these "corporation lawyers" organized multidepartment firms in which associates, recruited from the top of their classes at case-method law schools, competed for partnerships. "As a rule they are not conspicuous in public life," a journalist said of these Wall Streeters. "They are the silent, shrewd, polished, keen, erudite men who are the brains behind the vast organizations of capital they have helped create." Their fees were fabulous: $\$ 500,000$ to Francis Lynde Stetson for organizing U.S. Steel; $\$ 1,000$ a day to Elihu Root on another matter; a $\$ 100,000$ annual retainer to Paul Cravath; $\$ 1$ million to James Dill for settling a quarrel between two steel barons; and another $\$ 1$ million to William Guthrie for breaking a railroad magnate's will. ${ }^{23}$ Some lent their expertise to ad hoc commissions or took appointive offices at the request of Republican presidents, but they would never dream of seeking patronage or receiverships from Tammany judges. Their exclusive preserve was the Association of the Bar of the City of New York, known colloquially as "the City Bar."24

A crucial episode in their encounters with administration was the creation and early years of New York's public service commission. When Charles Evans Hughes made the commission his top priority as governor in 1907, he found that the state's railroad executives, on the advice of Wall Street lawyers, insisted that New York's appellate judges be able to decide for themselves whether the weight of the evidence supported its orders. Hughes rejected this demand for "a chance to go to the courts." De novo review of agencies' fact findings "would swamp your courts with administrative

22. Hindman, "Constitutional Convention," 51; see also Vernon A. O'Rourke and Douglas W. Campbell, Constitution-Making in a Democracy: Theory and Practice in New York State (Baltimore: Johns Hopkins Press, 1943), 163-64.

23. H. M. Stevens, "New York's Famous Lawyers," Harper's Weekly, July 29, 1911, 17.

24. Wayne K. Hobson, "Symbol of the New Profession: Emergence of the Large Law Firm, 1970-1915," in The New High Priests: Lawyers in Post-Civil War America, ed. Gerard W. Gawalt (Westport, Conn.: Greenwood Press, 1984), 3-28; Robert W. Gordon, "The Ideal and the Actual in the Law': Fantasies and Practices of New York City Lawyers, 1870-1910," in ibid., 51-74; Michael J. Powell, From Patrician to Professional Elite: The Transformation of the New York City Bar Association (New York: Russell Sage, 1988), 3-44. 
burdens and expose them to the fire of public criticism," he told the railroad men. "You must have administration, and you must have administration by administrators."2s

After Hughes prevailed, the corporation lawyers came around to his position. In retrospect, confessed Cravath, his fear of the commission seemed "ludicrous." "It is hard to believe that such opinions were entertained by intelligent men of affairs. Many of us now think the corporations would be better off if the commission were endowed with wider powers. One reason for this feeling is that we are relieved of our annual struggle with the Legislature, which was a perfect nightmare." ${ }^{26}$ When New York's utilities attempted to write strict judicial review into the state constitution in 1915, Elihu Root, the convention's president, blocked the effort. Administrative agencies were "inevitable," Root explained the following year, because they furnished "protection to rights and obstacles to wrongdoing which under our new social and industrial conditions cannot be practically accomplished by the old and simple procedures of legislatures and courts as in the last generation." Further, commissioners were more reliable than legislators, who too often brandished "strike bills" to extort payoffs from utility companies, or judges who tried to comprehend the needs of modern industry with antiquated common-law doctrines. ${ }^{27}$

The different responses of the courtroom lawyers of the NYSBA and the corporation lawyers of the City Bar to the spread of administration can be summed up in terms of a classic statement of the rule of law. In 1885 the Oxford law professor A.V. Dicey cast this ancient ideal as a principle of judicial supremacy, that no person ought to be punished or made to "suffer in body or goods except for a distinct breach of law established in the ordinary legal manner before the ordinary Courts of the land."28 Dicey's formulation could be stated as an institutional principle: any citizen whose rights were violated by an administrative agency ought to have a meaningful appeal to "the ordinary Courts of the land," where judges presided who were steeped in the principles of liberty embodied in the common law. A strong version held that courts ought to determine for themselves whether the weight of the evidence supported the factual findings of an agency. By

25. Charles Evans Hughes, "Speech before the Elmira Chamber of Commerce, May 3, 1907," in Addresses of Charles Evans Hughes, 1906-1916, 2nd ed. (New York, 1916), $185-87$.

26. "Find Service Boards Haven't Easy Tasks," NYT, December 17, 1911; see Bruce W. Dearstyne, "Regulation in the Progressive Era: The New York Public Service Commission," New York History 58 (1977): 331-47.

27. "To Limit Powers of Commissioners," NYT, July 20, 1915, 9; "Makes Tenure Sure for Service Boards," ibid., July 25, 1915, 13; Elihu Root, "Public Service by the Bar," $A B A$ Reports 41 (1916): 368-69.

28. Dicey, Law of the Constitution, 182-83. 
1938 American courts, "staggered by the immensity of the task of controlling the executive," had generally retreated to the more defensible position of accepting an agency's findings of fact if they were supported in the record by "substantial evidence"-that is, "such relevant evidence as a reasonable mind might accept as adequate to support a conclusion."29

In a few areas, however, the U.S. Supreme Court rallied the judiciary to the banner of weight-of-the-evidence review. In Ben Avon (1920) and St. Joseph Stock Yards (1936), for example, it instructed judges to determine for themselves whether the rates fixed by some regulator were so low as to confiscate the property of a regulated business. In Crowell v. Benson (1932), it told them to decide for themselves any "constitutional fact" that was "a condition precedent to the operation of the statutory scheme" entrusted to an agency. Under the Longshoremen's and Harbor Workers' Compensation Act, for example, federal judges were to make up their own minds about whether an injury occurred upon the navigable waters of the United States or in the course of employment. ${ }^{30}$

Dicey's rule of law could also be rendered in procedural terms: when acting in a judicial capacity, agencies had to use procedures that mimicked "the ordinary legal manner" of common-law courts. In April 1938 Chief Justice Hughes forcefully expressed this view in overturning U.S. Secretary of Agriculture Henry A. Wallace's order setting rates for the receiving and feeding of livestock at Kansas City's stockyards. Wallace had not followed "those fundamental requirements of fairness which are of the essence of due process in a proceeding of a judicial nature," Hughes declared. "If these multiplying agencies deemed to be necessary in our complex society are to serve the purposes for which they are created and endowed with vast powers, they must accredit themselves by acting in accordance with the cherished judicial tradition embodying the basic concepts of fair play." Wallace publicly protested, but Hughes held his ground. "Whatever the shortcomings of the courts, and whatever the need of administrative bodies," the chief justice insisted, "it is still the courts which stand out as the exemplars of the tradition of independence and impartiality." Thus, Hughes endorsed "administration by administrators," but only for administrators acting in "the spirit of the just judge." ${ }^{31}$ As the controversy over the anti-bureaucracy clause would show, his fellow corporation lawyers of the City Bar agreed.

29. Nathan Isaacs, "Judicial Review of Administrative Findings," Yale Law Journal 30 (1921): 789; Consolidated Edison Co. v. NLRB, 305 U.S. 197, 228 (1938). See Schiller, "Era of Deference," 399-412; E. Blythe Stason, " 'Substantial Evidence' in Administrative Law," University of Pennsylvania Law Review 89 (1941): 1026-51.

30. Ohio Valley Water Co. v. Ben Avon Borough, 253 U.S. 287 (1920); St. Joseph Stock Yards Co. v. United States, 298 U.S. 38 (1936); Crowell v. Benson, 285 U.S. 22, 54 (1932).

31. Morgan v. United States, 304 U.S. 1, 19, 22 (1938); "Address of Justice Hughes at Law Institute," NYT, May 13, 1938, 8. 


\section{Forming Ranks}

The New York constitution of 1894 provided that the convening of a constitutional convention be put to voters every twenty years. Neither party displayed much interest as the referendum approached in the fall of 1936, but, after their sweeping victory in the general election, the state's Democrats believed they could use the convention to entrench the little New Deal through reapportionment and other measures. ${ }^{32}$ George Fearon understood the stakes. "If the New Dealers control the coming convention," he warned, "you are going to have the same contempt for American institutions, the same disregard for our courts, the same centralization of authority, the same greed for power, the same disregard for individual and minority rights that we have had in Washington." But Fearon's fears proved unnecessary: when the convention delegates were chosen in the fall of 1937, Republicans won a clear majority, thanks to La Guardia's landslide reelection as New York City's mayor and the ALP's refusal to endorse the full Democratic slate. ${ }^{33}$

Among the elected delegates were two Republican lawyers from western New York, Ernest Leet and Arthur Eugene Sutherland, Jr. Both were alumni of the Harvard Law School. Leet graduated in 1926 and returned to Jamestown, New York. Sutherland graduated a year earlier and served as Justice Oliver Wendell Holmes's legal secretary before settling down to a substantial practice in Rochester. He was best known for his defense of a local grocer convicted for violating the state's milk control law, which produced the constitutional landmark, Nebbia v. New York (1934). ${ }^{34}$

Leet's conversion to Diceyism came when the state's Motor Vehicle Bureau denied his request for a stenographic record of a client's hearing in 1929. On that occasion he mobilized Jamestown's bar and forced the "dictatorial, vicious and undemocratic" bureau to back down, but he remained convinced that administrators continued to oppress New Yorkers in ways beyond the power of lawyers to correct. All they could do, Leet complained, was advise would-be clients to see "the right person" or work through "political channels." 35

In late 1937 Leet tried to rally bar leaders and the state Republican party

32. O'Rourke and Campbell, Constitution-Making, 62-68.

33. "Politics Ruling," NYT, August 20, 1938, 2; O'Rourke and Campbell, ConstitutionMaking, 79; Fearon quoted in O'Rourke and Campbell, Constitution-Making, 71; Hindman, "Constitutional Convention," 40-44.

34. Ernest D. Leet to Roscoe Pound, March 30, 1938, part 1, reel 34, Roscoe Pound Papers, Harvard Law School Library; "Arthur Eugene Sutherland, Jr., 1902-1973," Contemporary Authors Online (Gale, 2002), visited January 27, 2008; Erwin N. Griswold, "Arthur E. Sutherland," Harvard Law Review 86 (1973): 933-35.

35. New York State Bar Association, Administrative Law in New York (Albany, 1940), 224; Leet to Pound, March 30, 1938. 
behind a constitutional amendment but had little success. ${ }^{36}$ That left the initiative to a committee appointed by Governor Lehman, which, in turn, asked Louis Jaffe, a New Dealer on the University of Buffalo's law faculty, for a report on "Judicial Review of State Administrative Decisions." Jaffe's draft report denounced Ben Avon and Crowell as "excesses of judicial review" and opposed any change in the law. Although purged from the final report, the passages helped Leet persuade the NYSBA to take a stand. ${ }^{37}$ In March it created a committee on administrative law with a New York City lawyer, Edward Gluck, as its chair and Leet and Sutherland among its members.

At the committee's invitation, scores of trial lawyers sent in complaints about the state's administrators. Some lawyers reported that they had been forbidden to read or object to trial examiners' reports; others, that they had not been allowed to file a brief or argue before the official who actually decided their disputes. Some complained that referees in worker's compensation cases would "decide cases only one way"; others, that the Alcoholic Beverage Control Board did not give their arguments "a fair determination"; still others, that sales tax officials did not produce "proper records of hearings." 38

Above all, the NYSBA's lawyers objected to the substantial evidence rule. At the constitutional convention, the conservative Democrat Robert Whalen recalled an occasion when an employer sought his advice on whether to challenge a worker's compensation award in the courts. A worker had jammed his thumb and was laid off for a month, Whalen explained. The employer paid his wages in full and his doctor's bill and hired him back after his recuperation. Yet when the State Industrial Board learned of the accident, it set the matter down for a hearing on its own motion. The workman swore that he had suffered no permanent injury. "I can grasp a hammer just as well as I ever could," he testified. Three doctors, appearing on behalf of the employer, agreed, but the commission's own doctor testified that the worker had lost 40 percent of the use of his hand. The commission followed the

36. Leet to William A. Searle, March 28, 1938, reel 34, part 1, Pound Papers; Ernest D. Leet, "Address on Some Proposed Changes to the Constitution of New York State, Delivered before the Council of the Federation of Bar Associations of Western New York," Buffalo Daily Law Journal, December 21, 1937, 1, 3, 4, December 22, 1937, 1, 3.

37. Leet sent excerpts from Jaffe's draft to NYSBA president Joseph Rosch on March 30, 1938; see reel 34, part 1, Pound Papers; see also Leet to Pound, April 28, 1938, box 3, Committee Correspondence Hearings, Minutes and Proposals Files, New York State Constitutional Convention of 1938, New York State Archives, Albany, N.Y (NYSCC Papers). For the published version of Jaffe's report, see New York State Constitutional Convention Committee, Problems Relating to Judicial Administration and Organization (Albany, 1938), 781-845.

38. NYSBA, Administrative Law, 7, 112, 141, 189, 224-25. 
testimony of its doctor. Although the weight of the evidence argued for no award, the testimony of the commission's doctor was "substantial evidence in the case to support the finding," Whalen explained. "There was nothing to do but advise the employer that an appeal to the Appellate Division would be utterly futile." 39

Whalen declared the case an egregious example of a common phenomenon. Time and again he had seen appeals dismissed with a shrug. "Well, there is evidence in the case to support the findings," judges had said. "What can we do?" It was a great "anomaly," Whalen complained, for the factual findings of a commission, "composed perhaps of a former barkeeper or street cleaner," to be "absolutely conclusive and beyond the power of courts to review," when those of "a trained judge" were not. ${ }^{40}$

Although the NYSBA's trial lawyers would have nodded sympathetically, the City Bar's corporation lawyers saw more advantages than disadvantages in the administrative process. In October 1937 the ABA's chieftains tried to energize its Special Committee on Administrative law by appointing a new chairman, the former Harvard law dean Roscoe Pound. To counter this move, the City Bar, under the patrician Henry Stimson, created its own committee, with Felix Frankfurter as a member and John Foster Dulles as chair. ${ }^{41}$

Dulles took the job "with some reluctance and hesitation" and did not "feel particularly qualified to deal with this important subject," yet he quickly became a prominent and effective critic of heightened judicial review. He did find it "disheartening to be trying to defend the administrative procedure of a body like the S.E.C. when it goes on in ways which, justifiably or not, make litigants before it feel that they have not been accorded a treatment which meets the elemental requirements of justice." But the solution was for the agencies to reform their procedure themselves and not to "throw upon the courts the burden of curing" such deficiencies. ${ }^{42}$ As Dulles would later explain, "What people want is quick, efficient action. You go to a skilled surgeon and he finds a diseased spot. He takes a

39. Revised Record of the Constitutional Convention of the State of New York (Albany, N.Y., 1938), 3: 2064-65 ("Revised Record").

40. Ibid.

41. Resolution Adopted at the Meeting of the Executive Committee of the Bar Association, January 5, 1938, reel 77, Felix Frankfurter Papers, Manuscript Division, Library of Congress (FF-LC). On the ABA's committee, see Shepherd, "Fierce Compromise," 1569-79, 1582-83, 1588-93.

42. Henry L. Stimson to Felix Frankfurter, March 8, April 13, 1938, Dulles to Frankfurter, April 18, 1938, reel 77, FF-LC; see John Foster Dulles, "Administrative Law: An Address Given on January 14, 1939, at Langdell Hall, Cambridge," reel 59, John Foster Dulles Papers, Princeton University Library, Princeton, N.J.; "Joint Report of the Committees on Administrative Law and on Federal Legislation on S. 915 (76th Congress) introduced by Mr. Logan," May 2, 1939, reel 4, Dulles Papers; Dulles, "Administrative Law: A Practical Attitude for Lawyers," ABA Journal 25 (1939): 275-82, 352-53. 
knife and cuts it out with expertness, sureness of touch and a minimum of suffering. The body, relieved, goes on living. That is the kind of treatment which business and financial people, with whom I come in contact, expect of administration." Dulles would willingly exchange "a certain amount of classic legal protection" for the "valuable quid pro quo" of a quick and decisive conference with an expert official. ${ }^{43}$

Dulles's committee would not meet until May 11 and followed developments in Albany from a distance. In contrast, Leet and Sutherland actively pursued the interests of the NYSBA's trial lawyers at the convention-in Sutherland's case, as a member of the convention's Judiciary Committee. Their most effective opposition at the convention came not from New York City but from the Liberal Republicans and New Dealers of Buffalo's bench and bar.

\section{The Battle Joined}

When the constitutional convention convened on April 5, 1938, Liberal Republicans seemed to have the upper hand. One of their number, Charles Sears, presiding judge of the Appellate Division in Buffalo, was chosen to chair the Judiciary Committee. As the convention proceeded, however, the prospect that Liberal Republicans might join with New Dealers to pass major reforms drove Old Guard Republicans into revolt. Sears kept his chairmanship, but increasingly upstate Republicans combined with Tammany Democrats to seize the initiative. ${ }^{44}$

Previews of the convention made no mention of judicial review of administrative agencies. ${ }^{45}$ The New Dealers were satisfied with the deferential state of the law, and the Republicans, as Leet complained, lacked "any coordinated and intellectual approach to these problems." Nor did the NYSBA at first provide any guidance, as its administrative law committee could not unite on a single proposal. Over thirty amendments treating court review of agency decision making or the reform of administrative procedures were introduced in the first weeks of the convention and referred to Sears's committee. Gluck convened a meeting of the various sponsors in an attempt to settle on a single measure, but Philip Halpern (a Liberal Republican on the

43. "Statement of John Foster Dulles before the Attorney General's Committee on Administrative Procedure," July 12, 1940, reel 59, Dulles Papers.

44. Hindman, "Constitutional Convention," 50, 74-75; Stein, "Birth of Liberal Republicanism," 185, 189-93; O'Rourke and Campbell, Constitution-Making, 115, 205-6.

45. Food For Forums (February 1938): 17-18; Constitutional Convention Almanac, 1938 (New York: New York Times, 1938), 7-9. 
University of Buffalo's law faculty) and the counsel for the Department of Education opposed any attempt to heighten judicial review. ${ }^{46}$

Rebuffed, Gluck tried for a narrower consensus in a joint meeting of the NYSBA's committees on administrative law and the constitutional convention. When it ended Gluck thought all had agreed on language borrowed from the future Walter-Logan bill, recently approved by the ABA's Board of Governors. It directed reviewing courts to set aside findings that were "clearly erroneous or not supported by substantial evidence." Upon further consideration, however, several participants objected that the words "clearly erroneous" had no generally accepted meaning among the bench and bar and might not be read to require weight-of-the-evidence review. At last, in mid-July, the NYSBA's lawyers arrived at a solution. Borrowing from New York's Civil Practice Act, they proposed that the state's judges should overturn an agency's finding of fact whenever there was "such a preponderance of proof against" its existence that a jury verdict to like effect would be set aside by a trial court "as against the weight of the evidence." The Democrat Whalen and the Republican Sutherland introduced a resolution embodying the proposal, which was referred to the Judiciary Committee. ${ }^{47}$

The City Bar's committee followed the NYSBA's attempts to constitutionalize weight-of-the-evidence review with growing dismay. "Administrative law is in an evolutionary stage and inevitably subject to defects inherent in the early development of the process," Dulles wrote to Frankfurter. Constitutionalizing it now would lead to "undesirable rigidities and excessive detail." He then wrote to Sears in opposition to heightened judicial review. When administrators first exercised their quasi-judicial powers, Dulles allowed, their unfamiliarity with the "judicial approach" to fact finding sometimes led to abuses. The remedy was not to let courts second-guess their decisions but to ensure that administrators acted in "the judicial spirit of fairness and impartiality" in the first place. Weight-of-the-evidence review would produce needless cost and delay, destroy administrators" "sense of responsibility," and prevent administrative tribunals from evolving into "useful aids to society." ${ }^{48}$ Frankfurter, after huddling with Sears in Buffalo, telegrammed Dulles that the judge was "most anxious to have you appear personally before his committee because of [the] great weight which you

46. Leet to Searle, March 28, 1938; NYSBA, Administrative Law, 8, 114-35, 188-90; Leet to Pound, June 8, 1938, reel 34, part 1, Pound Papers.

47. NYSBA, Administrative Law, 8-11, 149-55, 161-62, 192-93. For the ABA Board of Governors' approval of the bill, see O. R. McGuire to Homer S. Cummings, May 12, 1938, box 4401 , entry 112 , RG 60 .

48. Dulles to Charles B. Sears, June 23, 1938, reel 3, Dulles Papers; Revised Record, 3: 2058-59. 
will carry in averting real danger of adoption of mischievous provisions." That proved impossible, however, as the Wall Streeter was "leaving at the end of this week to sail on the Eastern Yacht Club Cruise." 49

Meanwhile, at Leet's behest, Roscoe Pound treated the Judiciary Committee to a preview of his report on the evils of "administrative absolutism" for the ABA's Special Committee on Administrative Law. Sears countered with two New Dealers, Francis Shea, dean of the University of Buffalo's law school, and the Columbia law professor Walter Gellhorn. ${ }^{50}$ For days the committee remained deadlocked until at last, on July 19, it narrowly adopted the NYSBA measure, amended to apply only to newly created agencies, a compromise insisted upon by representatives of the Education Department and the worker's compensation commission. Sears dissented because he opposed any de novo review of agency fact finding; Whalen, because existing agencies were excluded. ${ }^{51}$

Before the convention could take up the committee's report, the report of a second ABA committee studying administrative law in 1938 reached the convention. The committee conducted a state-by-state survey of judicial review of administrative decisions and reached the stunning conclusion that New York's courts had been engaging in "practically no inquiry ... into questions of fact." Particularly alarming was its observation that New York courts had interpreted the phrase "weight of the evidence" to require only the existence of substantial evidence in the record. The NYSBA had assured New York's politicians that its amendment would, by using the phrase, require courts to engage in a stricter, de novo review. The clear implication of the ABA's report was that it would work no change in the law. ${ }^{52}$

From the opening of the convention, the NYSBA lawyers had tried to keep debate on administrative law from becoming openly partisan. Once judicial review became a question of "New Deal against Old Deal," Gluck realized, "emotion and politics" would be in the saddle. After the ABA report became public, emotion and politics took the reins from the lawyers. On the evening of August 3, the Democrat Whalen, identified in the press as "one

49. Frankfurter to Dulles, June 27, 1938, Dulles to Frankfurter, June 28, 1938, reel 3, Dulles Papers.

50. Leet to Pound, May 19, 1938, reel 34, part 1, Pound Papers; Diary, June 14, 1938, reel 42, part 2, ibid.; "Urges Court Reviews on Official Decisions," $N Y T$, June 15, 1938, 12; "Report of the Special Committee on Administrative Law," ABA Reports 63 (1938): 346-51; Minutes, June 14, 22, 1938, Judiciary Committee, box 2, NYSCC Papers.

51. "Bureaucracy Issue Splits Committee," July 20, 1938, 9; "Report of the Committee on the Judiciary," Document No. 8, Journal and Documents of the Constitutional Convention of the State of New York (Albany, 1938); Revised Record, 3: 2041; Hindman, "Constitutional Convention," 313-14.

52. Report of the Committee on Administrative Agencies and Tribunals, ABA Reports 63 (1938): 625, 627, 631; Warren Tubbs to Sears, July 18, 1938, box 3, NYSCC Papers; NYSBA, Proceedings, 1939: 193-94. 
of the most outspoken anti-New Dealers in the convention on either side of the house," moved the adoption of a substitute for the Judiciary Committee's report to provide for "judicial review ... u upon both the law and the facts" of any quasi-judicial order of an administrative agency ${ }^{53}$ Whalen exempted only three groups of administrators: tax assessors, worker's compensation commissioners, and "the educational system of the State." Nothing suggested that they were exceptionally faithful to the norms of judicial procedure; indeed, Whalen had illustrated the dangers of the substantial evidence rule with a worker's compensation case. His real aim, a delegate charged, was partisan, to take "a whack ... at the New Deal."

The delegates debated Whalen's substitute, which newspaper reporters dubbed "the anti-bureaucracy clause," well past midnight. ${ }^{55} \mathrm{Al}$ Smith marshaled the anti-New Deal Democrats behind the proposal, which he praised as a breakwater against "this wave that is going all over the country, of just taking hold of everybody and telling them what street they get off at." Upstate Republicans closed ranks with Smith's Democrats. George Fearon declared that Whalen's amendment would ensure that "some old lady, or some old man" wrongly denied a social security payment would get "a fair review by an impartial system." W. L. Burke rose to defend "the common man, the working man, the poor devil who would have to take it unless given some right of review of the actions of these boards." 56

On the other side of the question, Sears and Halpern spoke for the Liberal Republicans. Sears invoked Hughes, Dulles, Stimson, and Cuthbert Pound, chief judge of the state's highest court, as opponents of weightof-the-evidence review. ${ }^{57}$ For the New Deal Democrats, Robert F. Wagner predicted that New Yorkers would "overwhelmingly" reject a measure that would cripple unemployment insurance and other social welfare programs. Maldwin Fertig, a member of New York City's transportation board, warned that the clause would paralyze his agency but then blundered by invoking the authority of a recent symposium in the Yale Law Journal. Sutherland interrupted to ask Fertig to list its contributors; Felix Frankfurter's name drew jeers and laughter. Another delegate's question--did Fertig know "anything about the functional approach, as used in the Yale Law School in the teaching of law?"- produced more guffaws. $^{58}$

53. NYSBA, Administrative Law, 159-60, 208; "Judiciary Section Seen as Menacing All State Boards," NYT, August 14, 1938, 2; Revised Record, 3: 2069-70.

54. Revised Record, 3: 2088.

55. "Anti-Bureaucracy Clause," NYT, August 4, 1938, 6.

56. Revised Record, 3: 2064, 2091, 2101, 2106.

57. Ibid., 3: 2046-50, 2092-2100.

58. Ibid., 3: 2079-81, 2085-86, 2090. On Fertig, see Hindman, "Constitutional Convention," 57-58; "Maldwin Fertig, Legislator, Dies," NYT, July 24, 1972, 30. On the functionalist approach at Yale, see Laura Kalman, Legal Realism at Yale, 1927-1960 (Chapel Hill, N.C.: University of North Carolina Press, 1986), and Robert W. Gordon, "Professors and Policy- 
The conservative coalition of upstate Republicans and Tammany Democrats easily prevailed, and Whalen's amendment was cleared for final approval by a vote of 84 to 33 . Liberal Republicans accounted for "at least half" of the negative votes; New Deal Democrats made up the balance. ${ }^{59}$

From August 4 until the final vote two weeks later, the anti-bureaucracy clause was the subject of wide and overwhelmingly negative comment. "Courts have enough to do already without taking on the review of boards and commissions at the request or behest of any aggrieved individual or corporation," protested the patrician New York City lawyer Charles Culp Burlingham. "Shall the justices of New York's Supreme Court be required to count the number of bacilli in contaminated milk?" demanded the Rochester Times-Union. "Are they to be asked to grade examination papers for civil service jobs, and to pass on the eligibility of applicants for relief?" Even the Gannett chain of newspapers, not known for its liberal bent, came out against the clause. The New York State Federation of Labor denounced its likely effect on unemployment insurance and the state's labor board (which was more evenhanded in disputes between AFL and CIO unions than its national counterpart).$^{60}$ The Liberal Republican Edward Corsi scoffed at the notion that the clause would "give the little fellow relief against the encroaching power of bureaucracy." Instead, it would help "utility companies, railroads, oil companies and other large interests, who can hand down the cost of litigation to the consumer." Governor Lehman called the clause "extremely dangerous and unwise"; Mayor La Guardia thought it a brazen bid to establish "government by the courts."

When the anti-bureaucracy clause came before the convention for final passage on August 18, the NYSBA's lawyers tried to keep the debate on the proper plane. Leet called it "the most constructive step that we have taken here to restore our State government to a government of laws and not of men." Sutherland was still more lofty. "Now and then behind the particular and the specific there can be seen some great trend in the course of modern government," he declaimed. The "sudden and disproportionate growth in the executive branch" and the tendency to "exclude courts from sitting in judgment on all questions where their decision may come in conflict with executive desires" were not confined to New York or even the United States; they were part of "a world-wide process" that had "lately

makers: Yale Law School Faculty in the New Deal and After," in History of the Yale Law School: The Tercentennial Lectures (New Haven: Yale University Press, 2004), 75-137.

59. Revised Record, 3: 2110; "Curb on Bureaucracy Is Accepted at Albany after New Deal Fight," NYT, August 4, 1938, 1; "Judiciary Section Seen as Menacing All Boards."

60. "Judiciary Section Seen as Menacing All Boards"; Revised Record, 4: 3073, 3085-86; see Kim, "Labor Law and Labor Policy in New York State," 215-16.

61. "Curbing Bureaucracy," NYT, August 15, 1938, 14; "Lehman's Letter on Judiciary Plan," ibid., 2; "La Guardia Hits Reviews," ibid., August 5, 1938, 5. 
seen its greatest extension in some of the European states." Some delegates, Sutherland believed, were "impatient of the more deliberate processes of the Legislature and of the courts," but he hoped "that this body, with a solemn feeling of responsibility that rests upon every member here," would vote to preserve "something in our government which has today been thrown away in governments in other countries."62

Then the politicians took over. A member of Smith's bloc declared a vote for the Whalen amendment a vote against the "so-called sociological thought of the day, which builds up these bureaucracies." Another delegate, who confessed to being neither a "brain truster" nor "a brilliant jurist," likened the clause to a switch cut from "out behind the barn" and hung over a front door to warn a child to stop misbehaving. "Now we are putting a switch in the Constitution," he explained. "We are going to make these administrative bureaus toe the line." Fearon successfully proposed an amendment to permit courts to remand orders to the agencies that issued them and added the state's social security board to the list of exempted agencies. (Evidently word that federal administrators would cut off the state's funds if the clause were adopted overwhelmed Fearon's earlier solicitude for old ladies and old men.) A last bid by Sears to substitute a more agency-friendly measure failed, and the anti-bureaucracy clause was approved for submission to the voters in November. ${ }^{63}$

Wagner fretted, in a memorandum for Roosevelt, that "the vice of the proposal is obscured by its technical nature and attractive 'anti-bureaucracy' label," but he need not have worried. In the weeks between the convention and the general election, opponents all but drowned out supporters of the clause. La Guardia called it "outrageous, disgraceful," and "a vicious threat to orderly administrative government." "In Germany they do it with a brown shirt," he declared, "but here they do it with a black robe."64 Every New York City newspaper save the Sun came out against the clause; so did the Democratic, American Labor, Socialist, and Communist parties. The Republicans endorsed the measure, but the party's gubernatorial candidate, Thomas Dewey, joined other Liberal Republicans in opposing it. So did the Chambers of Commerce of Brooklyn and New York State, the Merchants' Association of New York, AFL and CIO affiliates, the Citizen's Union, and the City Bar. ${ }^{65}$ Gluck and Leet campaigned vigorously for the measure but were answered by other lawyers. Frank Shea, for example, neatly invoked

62. Revised Record, 4: 3076-77, 3083.

63. Ibid., 3087, 3093; Hindman, "Constitutional Convention," 318.

64. Robert F. Wagner, "Proposed N.Y. Constitutional Amendments," enclosed in Wagner to Roosevelt, August 31, 1938, Official File 88, Franklin D. Roosevelt Library, Hyde Park, N.Y.; "Court Review Plan Adopted at Albany," NYT, August 19, 1938, 20.

65. O'Rourke and Campbell, Constitution-Making, 220-22, 230-31; "City Bar Rejects Judiciary Article," NYT, October 19, 1938, 4. 
the rise of totalitarianism in Europe as an argument against intrusive judicial review. "The lesson of the consequences of a people's losing faith in a democratic government's capacity to respond to their essential needs is too current and too appalling," he observed. Under the anti-bureaucracy clause, generalist judges would overturn expert administrators, who would soon stop caring about their decisions and succumb to "the irresponsibility of negligent, half-hearted action." 66

In the end, the anti-bureaucracy clause was defeated by more than a twoto-one margin. The result was "a striking indication that the voting public were conscious of the movement toward a more inclusive executive branch, and favored it as the most effective means of carrying out the multitude of new and complex duties they expected government to perform," Sutherland reluctantly concluded. He and his fellow trial lawyers had misinterpreted the popular outcry against Roosevelt's Court-packing plan. They thought it was an endorsement of the "institutional" version of Dicey's rule of law, in which "the ordinary courts of the land" kept administrators in check. In fact, La Guardia's dismissive references to judicial review as "gowngovernment" better captured the popular mood. ${ }^{67}$

By rejecting institutional Diceyism, the defeat of the anti-bureaucracy clause staked out one legal and political boundary of an emerging consensus on the administrative state. As it happened, a second matter on New York's ballot that November fixed another. John Lord O'Brian had played no role in the constitutional convention of 1938. For most of the summer he had been closeted with the TVA's general counsel in Chattanooga as the two planned their second defense of the agency before the Supreme Court. On September 29, after a late evening at the TVA's offices, O'Brian returned to his hotel to find a sheaf of messages from Thomas Dewey, calling from the New York State Republican Convention. O'Brian reached Dewey, just named the party's gubernatorial candidate, and learned that he wanted him to run for the U.S. Senate against Robert F. Wagner. O'Brian told Dewey he did not want the job and went off to bed. The next day he learned from the morning's newspapers that he had been chosen after all. ${ }^{68}$

66. NYSBA, Administrative Law, 155-201, 213-35, 237-54; Frank M. Shea, "Shall Judicial Review Be Written into the Constitution?" Buffalo Daily Law Journal, November 4, $1938,3,4$.

67. O'Rourke and Campbell, Constitution-Making, 233; Arthur E. Sutherland, Jr., "Lawmaking by Popular Vote: Some Reflections on the New York Constitution of 1938," Cornell Law Quarterly 24 (1938): 11; "Bar Asks Review of Agency Orders," NYT, July 31, 1938, 14. La Guardia is quoted in Hindman, "Constitutional Convention," 377.

68. "The Reminiscences of John Lord O'Brian" (1952), 443-44, Oral History Collection, Columbia University, New York, N.Y. 


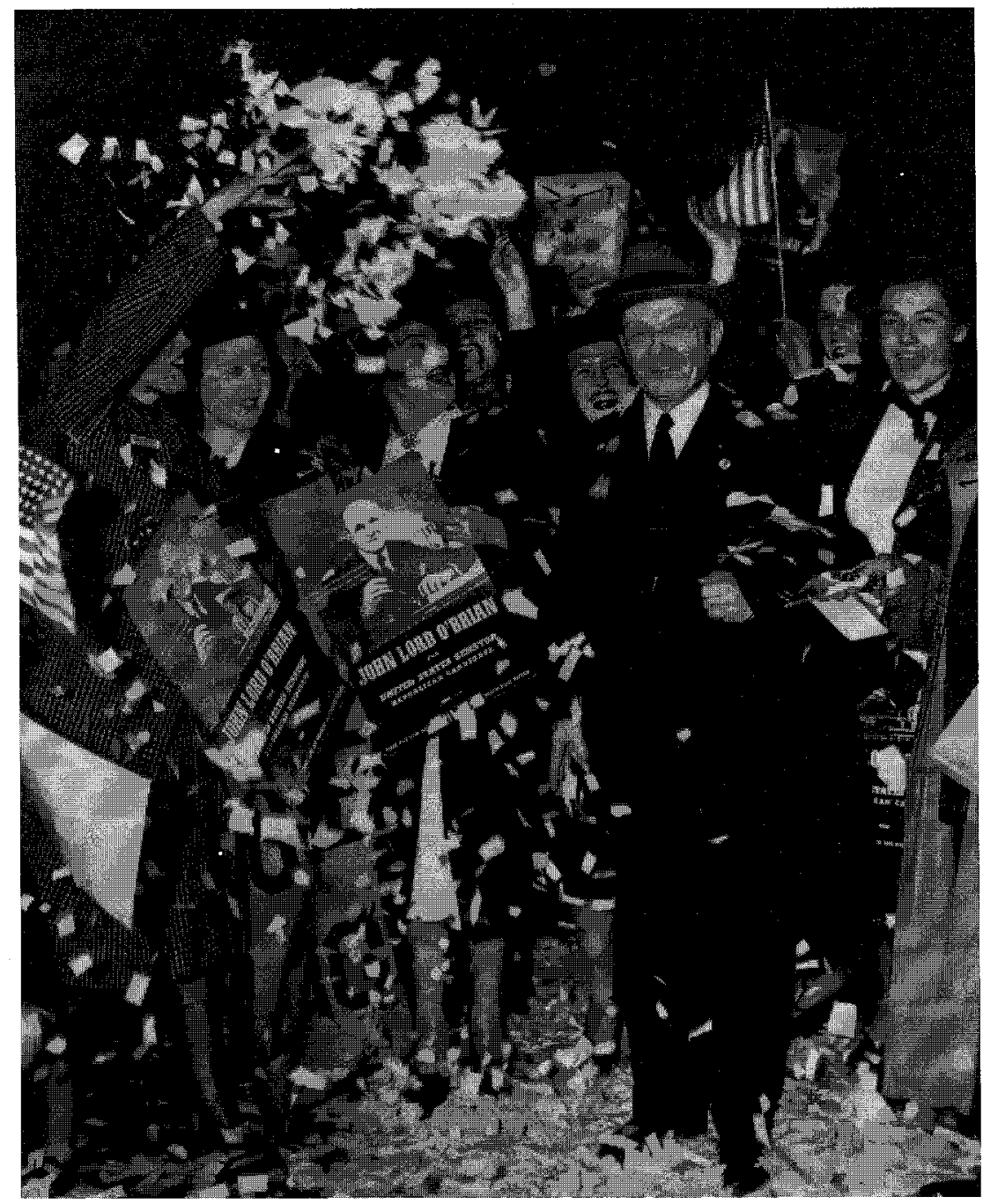

Figure 1. Members of the First Voters League cheer John Lord O'Brian as he prepares to depart Grand Central Station for Buffalo on Election Eve, 1938. 


\section{A Cicero from Buffalo}

O'Brian was sixty-four years old in the fall of 1938 . The nomination "comes at a late time in my career," he told a reporter soon after his selection. "I had no ambition for public office." 69 That may have been true, but O'Brian still believed, with his hero Elihu Root, that the law was a "public profession," and he was still willing to put a remunerative law practice on hold to act on that belief. His mother, a devout Episcopalian, had instilled in him a sense of Christian stewardship at an early age, and it survived an undergraduate education at Harvard, thought to be a godless place during the presidency of Charles Eliot. O'Brian did study with William James and George Santayana, but he also helped run a boys club at a Boston settlement house. The most galvanizing event of his college days was a talk to a gathering of Episcopalian students by a Harvard man then serving as the police commissioner of New York. O'Brian would never forget Theodore Roosevelt's admonition that college men should not let "their own ideals and high standards" keep them from entering the political ring. ${ }^{70}$

After Harvard, O'Brian returned to Buffalo, studied law in the evening, and gained some prominence as a speaker at literary events, a lawyer, and a lay minister to Episcopalians in the city's hinterlands. In 1906 he was elected to the state assembly, where he consistently supported Governor Charles Evans Hughes in the battle to bring progressive reform to the state. The two met when the young assemblyman spotted a legislative loophole that even Hughes, a masterful corporation lawyer, had missed. They saw each other regularly over the remainder of the session, and Hughes asked O'Brian to join his reelection campaign. ${ }^{71}$

Hughes proved to be O'Brian's entree to the patrician corporation lawyers of New York City. In 1909 Theodore Roosevelt appointed him U.S. Attorney for the Western District of New York; his duties brought him into contact with his counterpart in the Southern District, Henry Stimson. In 1913 he was a good-government candidate for mayor and was much celebrated by the civic elite despite his defeat. When New York's corporation lawyers, under Elihu Root's leadership, convened a committee to plan for the Constitutional Convention of 1915, they invited O'Brian, a delegate, to participate. During the convention he shared living quarters-dubbed the

69. "Dewey and Ticket at Odds on Issues," NYT, October 15, 1938, 1.

70. O'Brian, "Reminiscences" 1, 4-5, 8-10, 17-19; John Lord O'Brian, "Metropolitan Club-May 12, 1966," 5-6, box 57, John Lord O'Brian Papers, Charles B. Sears Law Library, University of Buffalo Law School, Buffalo, New York (O'Brian-Buffalo Papers).

71. O'Brian, "Reminiscences," 37-38, 41-47, 52-53, 56-57, 191; O'Brian, "Metropolitan Club," 8. See John Lord O'Brian, "Charles Evans Hughes as Governor," ABA Journal 27 (1941): 412-13. 
"House of Lords" by the state's politicos-with Stimson, George Wickersham (William Howard Taft's attorney general), and Charles Sears. As chairman of the Rules Committee, O'Brian became Root's lieutenant and confidante. He cherished his memories of their frank discussions and considered Root "the greatest man I have ever known."72

Further political and official assignments followed. Roosevelt asked him to second Stimson's nomination for governor in 1910, when the New York City lawyer engendered little enthusiasm among upstate Republicans. O'Brian was a member of the state's delegation to the Republican National Conventions in 1916 and 1920 and a contender for the Republican gubernatorial nomination in 1920 before giving way to a party stalwart. He was mentioned as a possible gubernatorial nominee in 1928, 1934, and 1936. ${ }^{73}$ He also made time for stints as a government lawyer. Woodrow Wilson's attorney general kept him as U.S. Attorney until 1914, then appointed him special counsel in the prosecution of a German provocateur, then made him chief of the Department of Justice's War Emergency Division. In that capacity he defended the Espionage Act of 1917 and personally ordered Eugene Debs's prosecution, but he also instructed U.S. attorneys not to "suppress honest, legitimate criticism of the administration or discussion of government policies," demanded solid evidence before interning enemy aliens, and disbanded his unit before a new attorney general, Mitchell Palmer, could get his hands on it. Later stints of government lawyering included a turn as Assistant Attorney General for the Antitrust Division, the defense of the TVA in the Ashwander and Nineteen Companies cases, and the general counselship of the War Production Board. ${ }^{74}$

In 1938 O'Brian had no illusions of defeating the New Deal's great tribune in Congress, who enjoyed broad support among New York's workers and immigrants. At least two major legislative landmarks were informally

72. O'Brian, "Reminiscences," 96-97, 108, 136-38, 142-45, 148-49, 167-69, 175. On Root and the "establishment" tradition he spawned, see Morton Keller, "The First Wise Man," American Lawyer (December 1999): 109; Alan Brinkley, Liberalism and Its Discontents (Cambridge, Mass.: Harvard University Press, 1998), 164-209.

73. O'Brian, "Reminiscences," 108-9, 119-23, 328-32; untitled note, enclosed with John Lord O'Brian to A.R.M., n.d., John Lord O'Brian Papers, Covington \& Burling, Washington, D.C. (O'Brian-C\&B Papers); "O'Brian of Buffalo Out for Governor," NYT, November 28, 1919, 5; "Miller and Wadsworth Win at Saratoga," NYT, July 29, 1920, 1; "Solid Delegation Urged by Morris," NYT, March 27, 1928, 3; "“Old Guard' Seeks Man for Governor," NYT, February 9, 1934, 20; "Brewster is Boomed for Governorship," NYT, July 30, 1936, 6.

74. O'Brian, "Reminiscences," 132, 223-48, 263-85, 334-40, 465-68; "Von Rintelen Spent $\$ 508,000$ in His Plot," NYT, May 2, 1917, 5; Michal R. Belknap, "John Lord O’Brian," American National Biography 16: 584; John Lord O'Brian, "Civil Liberty in War Time," in NYSBA, Proceedings 1919: 275-313. See William H. Thomas, Jr., Unsafe for Democracy: World War I and the U.S. Justice Department's Covert Campaign to Suppress Dissent (Madison, Wis.: University of Wisconsin Press, 2008), 27-28, 87,156,176-77. 
known as "Wagner Acts"- the National Labor Relations Act of 1935 and the Housing Act of 1937--and the senator had helped pass many others. Although in poor health, Wagner still had the energy to campaign, over the protests of his advisors, "at every dinky club-house, rally, and gathering" in New York City. ${ }^{75} \mathrm{O}$ 'Brian's defense of the TVA gave him a measure of bipartisan appeal, as Attorney General Robert Jackson backhandedly acknowledged in announcing the postponement of the argument of the Nineteen Companies case until after the election. "We are not unappreciative of the compliment implied," Jackson deadpanned, "when the Republican convention finds its best man for this high office on the legal staff of this Administration." 76 But most New Yorkers knew so little about the Buffalo lawyer that he was obliged to entitle a press release "Who Is John Lord O'Brian?"77 One friend spoke of "the tremendous odds" O'Brian faced; another thought his task so hopeless that "I could hardly escape wondering why you could bring yourself to undertake it." 78

As low as expectations were for his candidacy, O'Brian went out of his way to lower them further. "The people need not expect pyrotechnics," he told reporters. "It is vitally important that the truth be told concerning certain vital policies of the administration with which my opponent has identified himself; and on this basis I intend to wage my modest campaign." Yet from his first speech on October 15, 1938, O'Brian discovered that the issue he cared most about as a lawyer in the late New Deal-due process in the midst of a growing administrative state-directly addressed a major political controversy of the day, the NLRB's seeming favoritism for the industrial unions of the $\mathrm{ClO}$ over employers and the craft unions of the AFL. By attacking the procedures of the NLRB he could defend a cause he believed in and gain ground on his opponent, who was too closely identified with the board to shrug off its shortcomings. In early November even Wagner's lieutenants thought O'Brian might possibly win. ${ }^{79}$

By the fall of 1938 O'Brian had come to embrace the procedural variant of Dicey's rule of law. He accepted that administrative agencies were necessary to hold in check the "social forces" that "inevitably narrow the scope of the individual's activity" in modern times. Although he believed

75. Wagner's advisors quoted in J. Joseph Huthmacher, Senator Robert F. Wagner and the Rise of Urban Liberalism (New York: Atheneum, 1968), 253.

76. “TVA Case Put Off For O'Brian's Race," NYT, October 4, 1938, 34.

77. Press release, "Who Is John Lord O'Brian?" n.d., box 407, Robert F. Wagner Papers, Georgetown University Library, Washington, D.C..

78. Philp [Besser Gratz] to O'Brian, November 10, 1938, box 49, O'Brian-Buffalo Papers; Noel T. Dowling to O'Brian, November 19, 1938, ibid.

79. “O'Brian Offices Here," NYT, October 14, 1938, 7; Huthmacher, Wagner, 251. 
in the procedures of common-law courts, he also thought that administrators could not do their jobs if courts second-guessed the factual basis for their orders. Apparently that had not always been his position. In an address to the New York State Republican Convention in 1920, he blamed federal administrators for embracing "a continental conception of administrative law foreign to the spirit of the American Constitution." He drew a distinction "between the old American idea of government by laws and this so-called government administered through the edicts of subordinate officials, uncontrolled by constitutional limitations, and whose powers lie outside the control and review of the courts." Doubtless many conservative Republicans applauded his denunciation of the Bureau of Internal Revenue and the Federal Trade Commission for "disposing of our property rights, administering our affairs, and ruling us," but perhaps fewer agreed when he attacked Postmaster General Albert Burleson's suppression of radical literature or called the Palmer Raids of 1919-20 the most alarming recent illustration of "the menace of administrative law."80

Whatever his views in 1920, by the late 1930s O'Brian agreed with the City Bar's leaders that the answer to capricious administrators was not heightened judicial review but administrative procedures that mimicked the courts. "It is impossible for the Appellate Courts on a cold record to deal with questions on the weight of the evidence," he told the American Law Institute in May 1939. "The evils of the present situation cannot be satisfactorily dealt with by enlarging the judicial power of review." The "crucial question," O'Brian maintained, was how "findings of fact are to be arrived at" within an agency and whether its procedures were consistent with our "tradition of fair play."81

In two disputes before his senatorial campaign O'Brian insisted that agencies treat his clients in the ordinary legal manner of the ordinary courts of the land. The first was the SEC's attempt in the summer of 1936 to outlaw "wash sales" in a hearing before the Yale law professor Thurman Arnold, serving as a special examiner. O'Brian moved for a bill of particulars to limit the SEC's case, and he objected so frequently and presented his own case so methodically that a despairing Arnold declared the hearing "perfectly interminable." At last he took over the examination of O'Brian's witnesses

80. "Proceedings of the State of New York Republican State Convention Held at Carnegie Hall, New York City, February 19-20, 1920," 101-02, box 57, O'Brian-Buffalo Papers; John Lord O'Brian, "The Menace of Administrative Law," Maryland State Bar Association 1920: 156. On the FTC, see George Sutherland, "Private Rights and Government Control," $A B A$ Reports 42 (1917): 204-7.

81. Remarks of John Lord O'Brian, American Law Institute, May 12, 1939, Personal Notebook, 90-95, box 50, O'Brian-Buffalo Papers; see also "O'Brian Decries Control before Law Institute," NYT, May 13, 1939, 17. 
himself. "I irritated John Lord Bryan [sic], who is a very nice person," Arnold reported to his wife. "After protesting vigorously, he asked for an adjournment and said he would shorten his case. I hated to do it, but if I let them run they will be going all winter." 82

O'Brian entered a second suit, brought by the USDA's Bureau of Animal Industry against Swift and Company under the Packers and Stockyards Act, in November 1936. Many New York City wholesalers had reported that Swift gave small retailers discounts and easier credit than they received and that the company shipped its goods only on railroads and steamships that bought its products for their dining cars and commissaries. But when the Bureau's lawyer arrived in New York to prepare for the hearing, he found the wholesalers and purchasing agents too afraid even to tell him the names of their salesmen. The leading wholesaler proved to be wholly untrustworthy; other jobbers had made statements that "were not in accord with the facts, or facts to which they could testify." Under the circumstances, the lawyer had to use the hearing to elicit what he knew was hearsay evidence-ccertainly not of the kind that would stand up in any court action"-in the hope that, when "confronted by these statements under oath," witnesses might be induced to "come much nearer to telling the truth." "It is a case of digging for evidence," the lawyer confessed to his superior. "Hearsay testimony is being put in merely to develop leads whereby real evidence may be obtained later on. These people will not come in and tell their story without being subpoenaed and put on in the open hearing. All the meat industry up here seems to be afraid of the big packers." 83

O'Brian saw what the government was up to and protested that Swift was being "persecuted under the guise of a government hearing." 84 As in the SEC case, he moved for a bill of particulars to limit testimony; he insisted that every invoice be shown to date from a relevant time period; and he repeatedly objected to testimony as "incompetent, irrelevant, and immaterial." "No criminal case was ever conducted with more technicality than Mr. O'Brian is attempting to inject in the record," the Bureau's lawyer complained. The lawyer understood that the Bureau might lack the funds to conduct "a long drawn-out hearing"; still, he was "prepared to go the limit." The hearing proceeded, and the trial examiner upheld some (but not

82. Thurman W. Arnold to Frances Arnold, August 6, 1939, box 10, Thurman W. Arnold Papers, American Heritage Center, University of Wyoming, Laramie, Wy.; see "Says He Was Offered Stock by White, Weld," NYT, July 16, 1936, 34; "Broker Defies SEC in A. O. Smith Case," NYT, July 17, 1936, 23.

83. Mastin G. White to J. R. Mohler, November 24, 1936, box 28, entry 70, Records of the U.S. Department of Agriculture, Record Group 19, National Archives II (RG 19); A. W. Miller to White, July 24, 1936, ibid.; C. B. Miles to White, January 16, 24, February 10, 1937, ibid.

84. "Swift \& Co. Protest Federal Hearings," NYT, January 16, 1937, 31. 
all) of the complaint's counts. O'Brian persisted as well. He restated his evidentiary objections to Secretary Henry Wallace and added the unfairness of having to proceed without a brief from the government. When Wallace ruled against him, O'Brian appealed to the federal judiciary, which fully exonerated his client. ${ }^{85}$

O'Brian never represented employers before the NLRB; in fact, he had defended Buffalo's clothing workers during a strike in 1923, which was probably why he was offered the chairmanship of the NLRB in $1935 .{ }^{86}$ Although he declined that post, he agreed to chair the ABA's Standing Committee on Labor, Employment and Social Security the following year. In a report written before his senate race, O'Brian endorsed the "underlying philosophy" of the Wagner Act, but he criticized the statute for punishing only employers for unfair labor practices, because this made the NLRB's members "the partisans of one class as against the other." Its lawyers acted "virtually as prosecutors" and made their case to the Board's own trial examiners, who were predisposed to rule against employers. Facts found by the NLRB were practically binding upon a reviewing court, thanks to the substantial evidence rule. In sum, the Board was violating "the traditional requirements of fair play" and had therefore lost "the confidence of the public at large." 87

Businessmen had their own, more heated verdict on the NLRB, captured in the title of a widely noted article in Fortune: "The G-- D--- Labor Board." A well-funded litigation campaign had kept the Board in limbo for almost two years after its creation in $1935 .^{88}$ After the Supreme Court upheld its constitutionality in the Jones \& Laughlin decision, however, it received thousands of requests to hold elections for collective bargaining agents and thousands of complaints against employers. As the Board's activity picked up, the economy slowed down; the "Roosevelt recession" gave employers and their Congressional allies a new line of attack. Senator Edward Burke, for example, told an appreciative U.S. Chamber of Com-

85. John Lord O'Brian, "Petition to Set Aside the Order of the Secretary of Agriculture Dated June 1, 1938," Miles to White, January 24, 1937, Respondent's Statement of Exceptions to Examiner's Actions at the Hearing," box 28, entry 70, RG 19; Swift \& Co. v. Wallace, 105 F.2d 848 (7th Cir. 1939).

86. Henry J. Winters to Benedict Wolf, October 29, 1938, box 406, Wagner Papers; O'Brian, "Reminiscences," 321-22, 456; "Senatorial Battle Page," New York Daily News, October 19, $1938,32$.

87. "Report of the Standing Committee on Labor, Employment and Social Security" $A B A$ Reports 63 (1938): 269-70; see also ibid., 61 (1936): xxx; 62 (1937): 30, 708-10.

88. "The G-- D--- Labor Board," Fortune 18 (October 1938): 52-57, 115-18, 120, 23; Peter Irons, The New Deal Lawyers (Princeton: Princeton University Press, 1982), 243-48; Ronen Shamir, Managing Legal Uncertainty: Elite Lawyers in the New Deal (Durham, N.C.: Duke University Press, 1995), 85-86. 
merce that the Board's orders would "snuff out the fires of industry and send millions of workers into the line of the unemployed." 89

Congressional conservatives like Burke, a Nebraska Democrat outraged by Roosevelt's channeling of the state's patronage through the Progressive Republican George Norris, viewed the NLRB as part of a New Deal plot to remake the Democratic Party. Their fears grew during the primary season of 1938 when the president campaigned against Democrats who had opposed the Court-packing plan. The purge failed almost everywhere, but it convinced party stalwarts that their combat with the New Dealers was mortal. After the November elections, congressional leaders made their opposition public. ${ }^{90}$ "We have got to do something about those fellows downtown who think they can run the Government any old way that pleases them," declared Francis Walter. The ABA's bill, the Hatch Act, which forbade political activity by federal employees, and legislation to remake "that God damn NLRB" were all intended to block the New Dealers' schemes. ${ }^{91}$

The NLRB had another dangerous enemy in the AFL, which objected to its recognition of CIO affiliates as workers' representatives. When the Board certified the CIO's longshoremen's union instead of the AFL affiliate in June 1938, the older federation mounted, in Christopher Tomlins's words, an "all-out war against the NLRB." In August President William Green asked Roosevelt and Wagner to amend the act and denounced the labor board as "a travesty on justice." Meanwhile Green's general counsel met secretly with employers' lawyers in search of common ground. The general counsel favored a new administrative tribunal to hear appeals from the NLRB; the employer's lawyers countered with weight-of-the-evidence review in the federal courts. In October, the AFL's annual convention directed the Executive Council to study both proposals and called for a more modest set of reforms. ${ }^{92}$

More generally, public opinion was running against the NLRB in the fall of 1938. Although the Supreme Court consistently upheld the Board,

89. Christopher L. Tomlins, The State and the Unions: Labor Relations, Law and the Organized Labor Movement in America, 1880-1960 (New York: Cambridge University Press, 1985), 200; William E. Leuchtenburg, Franklin D. Roosevelt and the New Deal, 1932-1940 (New York: Harper \& Row, 1963), 243-44; "400 in Chamber Unanimous in Vote for Inquiry by Congress," Washington Post, May 4, 1938. On Burke, see Patterson, Congressional Conservatism, 47-49.

90. Kenneth S. Davis, FDR: The New Deal Years, 1933-1937 (New York: Random House, 1986), 631; Leuchtenburg, Franklin D. Roosevelt, 266-70; James A. Gross, The Reshaping of the National Labor Relations Board: National Labor Policy in Transition, 1937-1947 (Albany, N.Y.: State University of New York Press, 1981), 68-71; Patterson, Congressional Conservatism, 316-18.

91. Walter Gellhorn, "Memorandum of Conversation with Congressman Walter," June 2, 1939 , box 8 , entry 376, RG 60 .

92. Tomlins, State and the Unions, 160-84; Gross, Reshaping, 50-68; "State A.F.L. Hits NLRB ‘Prejudice,"” NYT, August 26, 1938, 1. 
newspaper and magazine editors and columnists consistently condemned it. Collier's, for instance, declared the NLRB "the most glaring example" of the "rank partisanship of some of our federal boards." A Gallup poll conducted in the summer found that, of those with an opinion of the Board, more than two thirds thought it biased in favor of unions. ${ }^{93}$ Another poll, published just after the congressional elections, found that 70 percent of respondents believed the Wagner Act should be revised or repealed, up from 62 percent in May. So widespread was dissatisfaction with the NLRB that a sarcastic reference to the Wagner Act was sure to get a laugh at the New York constitutional convention. When, one day in August, Wagner declared some proposal to be unfair, George Fearon leapt to his feet. "This is just' too much, Mr. Chairman, when the author of the National Labor Act gets up and talks about fairness," the Republican stalwart cried. "God forbid that he should be any judge of the meaning of the word."

In short, once O'Brian got over the shock of his nomination, he must have warmed to the idea of campaigning against Wagner and the NLRB, because it gave him the opportunity to defend the rule of law in an unusually receptive political environment. Even the presence of the anti-bureaucracy clause on the ballot was advantageous, because it would make O'Brian's procedural reforms seem more moderate and reasonable. A clue to his thinking may be found in one of his conversations with Root during the constitutional convention of 1915. "I expressed the view that it was foolish for us to try to dogmatize too much about the future operation of any of these measures that we were talking about; that after all the thing to do was to get a fundamental principle firmly established and then trust to public opinion and let it grow, let it evolve.' O'Brian remembered his unsuccessful campaign for mayor of Buffalo in just these terms. Although he never had much chance of winning, he considered the campaign a success because it demonstrated the power of "the 'good government' element" and ultimately brought commission government to the city. "My campaign," he believed, "had in reality accomplished its objectives in spite of my defeat." 95 If O'Brian could do for due process in 1938 what he had done for good government in 1913, he would not have to defeat Wagner to win.

\section{It Might Be Done}

Within a week of O'Brian's nomination, the New York Times's Arthur Krock declared his challenge "one of the most interesting contests in the current

93. Gross, Reshaping, 35, 72; "Fair Play," Collier's 101 (June 25, 1938): 70.

94. "Fight on Measure Due in Next Congress," NYT, November 13, 1938, B3; Revised Record, 4: 2947.

95. O'Brian, "Reminiscences," 168, 123-24. 
campaign." If O'Brian mounted "a frontal attack on Senator Wagner," Krock wrote, his race would become a referendum on "the extremes of the New Deal." In particular, "Mr. O'Brian has everything to gain and nothing to lose by making an issue of the Wagner act." The CIO had already endorsed the incumbent, but the AFL could still be divided, "unless Mr. Wagner goes so far in proposing amendments as to vex his CIO followers." In addition, a vigorous attack on the NLRB would give the businessmen who might otherwise stay home a reason to turn out. "Mr. Wagner will be a hard man to beat this year," Krock acknowledged, but if O'Brian was bold "it might be done."96

O'Brian opened his campaign in Buffalo on October 15, less than a month before the election on November 8 . In an address to a group of young Republicans, he criticized Wagner for "bungling" the administration of public relief; for backing the National Industrial Recovery Act, which had visited a plague of anticompetitive practices on American industry; and for his silence on Roosevelt's Court-packing plan. O'Brian's main target, however, was the NLRB. The Roosevelt recession, O'Brian observed, had returned business and labor to "just about where we were in 1933." It was the product of "the general sense of insecurity and uncertainty ... resulting from the operations of the National Labor Act," which had "split the ranks of labor and ... brought confusion and demoralization into business and industry" throughout the nation. ${ }^{97}$

O'Brian declared himself in full accord with the Wagner Act's basic principles. He wanted to see collective bargaining firmly established, workers free to present their complaints "informally and inexpensively," and their disputes "quickly disposed of by a fair hearing." Such a hearing was impossible, however, as long as the NLRB was both prosecutor and judge. The labor board "files a complaint with itself," O'Brian explained. "To hear and try out the complaint the Board appoints a Trial Examiner whose salary is paid by it." Next, "the Trial Examiner holds a hearing or trial and later reports his recommendations to the Board. The Board itself then reviews the record and makes the final decision upon the complaint originally filed by it, prosecuted by it, and heard by its Trial Examiner." If the record thus produced contained "any substantial evidence which will support its decision on the facts, the findings of the Board as to these facts are binding upon the courts." ${ }^{98}$

96. Arthur Krock, "In the Nation: The Republican Tactics in New York," NYT, October $6,1938,22$.

97. John Lord O'Brian, Address to the Young Men's Republican Clubs of the Eighth Judicial District, Buffalo, N.Y., October 15, 1938, 4, 9-11, box 407, Wagner Papers (O'Brian, Buffalo Address).

98. Ibid., 5. 
O'Brian knew that the ancient maxim "no one should be a judge in his own cause" had often been leveled against administrative agencies without success. ${ }^{99}$ As James Landis, dean of the Harvard Law School, argued, "a succession of practical legislative judgments" suggested that the dangers combining prosecutorial and judicial functions posed for the administrative process were worth braving because courts were unable to handle certain classes of disputes. These dangers could be kept at bay if administrators developed "a spirit of professionalism," consistently followed their own precedents and procedures, and justified their orders with "detailed and informative" findings of fact. ${ }^{100}$ Had O'Brian known of the actual practice of fact finding at the NLRB, where, as Louis Jaffe later conceded, young lawyers sometimes found "facts as we wanted to have them be," he might have shown that the Board lacked the very safeguards Landis named. ${ }^{101}$ Under the circumstances, the best he could do was to distinguish the NLRB from, say, the Interstate Commerce Commission on the rather unconvincing ground that the labor board dealt with "fundamental questions of human right and even of human liberty," while other agencies handled "minor administrative questions"- hardly an apt description of the regulation of the nation's railroads and trucking industry! ${ }^{102}$

O'Brian promised to reform national labor policy in four ways. First, he endorsed most of the changes called for by the AFL at its convention, including notice of hearings to all interested parties, who were empowered to subpoena witnesses; a ban on "secret reports and files"; and the hiring of better trial examiners. Second, O'Brian would let employers ask the Board to hold an election in a dispute between rival unions to determine which one should represent their workers. (The NLRB only allowed employees to request an election.) Third, he would separate the functions of prosecutor and judge. The existing NLRB would continue to investigate disputes and prosecute complaints, but "a different and impartial board" would be created to rule on them. Finally, O'Brian promised to end "the partiality and open partisanship" of the present members of the Board, presumably by blocking their reappointment. He closed with an appeal to New York's

99. See, for example, National Harness Manufacturers Association v. Federal Trade Commission, 268 F. 705 (6th Cir. 1920).

100. James M. Landis, The Administrative Process (1938; New Haven, Conn.: Yale University Press, 1966), 95, 99.

101. Louis L. Jaffe, interview by Jerold S. Auerbach, July 10 to September 22, 1972 , 95, box 38, Dorot Jewish Division Oral Histories, New York Public Library. Other lawyers recalled being instructed to find facts that had no basis in the record. Wallace $\mathbf{M}$. Cohen, interview by Judith Byne, March 21, 1969, NLRB Oral History Project; Ida Klaus, interview by Judith Byne, February 27, 1969, NLRB Oral History Project.

102. O'Brian, Buffalo Address, 6. 
workers: "Whatever may be said by partisans or professional leaders I feel confident that the suggestions which I have made will, on reflection, commend themselves to the great mass of the rank and file of wage earners themselves, and I rest my plea for reasonableness on that confidence."103

In appealing to labor, O'Brian probably remembered the friendly reception Buffalo's workers gave him, "as a sporting proposition," during his mayoral campaign. ${ }^{104}$ Yet his repeated endorsements of the principle of collective bargaining and the AFL's reforms brought no show of support from workers or unions. Instead, middle-class and elite voters came out for him with unexpected enthusiasm. A cadre of young adults, the First Voters League, organized a "John Lord O'Brian Minute Men Division" to canvass New York City. The League's members showed up at rallies with banners proclaiming "Youth Wants O'Brian" and "John Lord O'Brian for Senate," with the capital letters $\mathrm{J}, \mathrm{O}, \mathrm{B}$, and $\mathrm{S}$ in boldface. ${ }^{105}$ More weighty was the financial support of New York City's legal elite. A citizen's committee, including such legal titans as Arthur Ballantine, Charles Evans Hughes, Jr., Stimson, and Paul Windels, was formed under the chairmanship of a member of the City Bar. Its contributions funded six statewide radio addresses. On October 21 Stimson weighed in with a lengthy letter to the New York Times that attacked Wagner for failing to oppose the Court-packing plan and for the one-sidedness of his National Labor Relations Act. O'Brian, in contrast, had "the courage, the fair-mindedness, and the ability of a great citizen and public officer" and "the kindliness and uprightness of a loyal friend." 106

As late as October 23, the New York Daily News thought the WagnerO'Brian race "so one-sided" that the average voter refused to "get steamed up over it." On that date, however, O'Brian challenged Wagner to debate "in what respect, if any, should the national labor relations act be amended?"'107 The gambit presented Wagner with a dilemma. In all likelihood he knew of procedural irregularities at the NLRB from his meeting with AFL leaders, talks with the Board's regional director in New York, and other sources.

103. Ibid., 6-8.

104. O'Brian, "Reminiscences," 123-24.

105. O'Brian's Reply to Questions Asked by Times," NYT, October 22, 1938, 2; “O'Brian Asserts Campaign Issue Is Job Security," New York Herald Tribune, October 19, 1938, 3; “As Young Voters of Westchester Hail John Lord O'Brian," New York Herald Tribune, October 23, 1938, sec. II, 2; "First Voters League to Form O'Brian Unit," New York Herald Tribune, October 24, 1938, 2; “O'Brian Jobs Brigade Launches Campaign to Elect Him," New York Herald Tribune, November 3, 1938, 7.

106. "O'Brian Group is Formed," NYT, October 22, 1938, 2; "New York's Senatorial Candidates: Mr. Stimson Advances Arguments in Favor of the Election of John Lord O'Brian to Congressional Seat," ibid., October 21, 1938, 22.

107. "Lehman Endorses Two New Dealers," New York Daily News, October 23, 1938, 20; New York Herald Tribune, October 24, 1938, 1. 
As Krock had reasoned, with the AFL in open revolt, he could scarcely pretend that the administration of what he liked to call "my labor relations act" was beyond reproach. But were he to explain how his statute and the Board should be reformed, he risked alienating the CIO and opening the door to drastic changes by congressional conservatives. ${ }^{108}$

Until O'Brian's challenge, Wagner's preferred course was to concede that the act was not perfect, to promise to consider "any proposal to strengthen and improve the basic purposes of the law," and to deride his critics. He urged audiences not to be fooled by the "synthetic coating of liberalism" recently applied to the "reactionary Republican elephant." Republicans were still plotting "to press the thorns of industrial slavery and yellow dog contracts upon the sweated brow of labor." So-called liberals in the GOP's ranks were "indulging in camouflage"; they were "last minute hitchhikers seeking a free ride on the progressive bandwagon." Republicans revealed their true colors when their party endorsed the constitutional convention's anti-bureaucracy clause, which would "hamstring the Public Service Commission and clog the courts." 109

Because so many newspapers had excoriated the NLRB--even the Daily News, solidly in the senator's camp, attacked it-Wagner knew that the press would applaud O'Brian's challenge, and he took several days to formulate a response. ${ }^{110}$ At last on October 25 he replied that although he would have happily debated his opponent a week earlier, the intervening publication of O'Brian's answers to questions submitted by the New York Times showed that his opponent was committed to the same views as "Mr. Hoover, Mr. Landon and their spokesmen in the United States Senate." His own views, Wagner continued, were "in square opposition" and had already been reported "times without number." He then released his responses to the New York Times's questions. In combining investigatory and quasijudicial functions, he argued, his statute had followed the example of the Interstate Commerce Commission, the Federal Trade Commission, and "innumerable other Federal and State regulatory agencies." The Supreme

108. Elinore Herrick to Robert F. Wagner, August 6, 1938, box 6, Wagner Papers; Gross, Reshaping, 117-20.

109. All in box 2, Leon Keyserling Papers, Georgetown University Library, Washington, D.C.: "Keynote Speech of Senator Robert F. Wagner at New York State Democratic Convention, Rochester, N.Y.," September 29, 1938; "Speech of U.S. Senator Robert F. Wagner at Ratification Meeting, National Democratic Club, New York City," October 14, 1938; "Speech of U.S. Senator Robert F. Wagner at Binghamton," October 20, 1938; "Speech of U.S. Senator Robert F. Wagner at Albany," October 24, 1938.

110. "Senator Robert F. Wagner," New York Daily News, November 3, 1938, 33; Mark Sullivan, "Wagner and the Sit-Down Strike: Operation of Labor Act Poses Questions of Him as Candidate," New York Herald Tribune, October 23, 1938, sec. II, 2; "Wagner Silent on Challenge," New York Herald Tribune, October 25, 1938, 2. 
Court had upheld the NLRB's procedures in Jones \& Laughlin, a decision, he suggested, that "Mr. Henry L. Stimson" might want to read. The statute was not one-sided; it simply addressed a specific evil, violent resistance to workers' rights to organize and to bargain collectively. Wagner closed by observing that he had never maintained that the National Labor Relations Act was perfect, but he neglected to say how it might be improved. ${ }^{111}$

"How lame and cheap his excuse!" exclaimed the Herald Tribune. "How disappointing!" Wagner had passed up the chance to debate "a subject of vital moment to the country with an opponent at once thoroughly respectful and worthy of his steel." "Every voter on Election Day should cast for him not a ballot but a white feather." Other newspapers piled on. The New York World Telegram called Wagner's refusal "a big campaign surpriseand disappointment"; the Syracuse Post-Standard thought the senator was running scared; the New York Daily Mirror demanded, "Is Senator Wagner a statesman or a stooge?" O'Brian called Wagner "a standpatter and not a liberal." "The public can judge which of us is the more sincere," he told a gathering of Republican women. "Senator Wagner has not only refused to meet me in debate"; he had entirely ignored the main issue of the campaign, "how jobs can be restored to the people who want work." 12

Over the next days Wagner defended his refusal to rebut O'Brian's "calculated sophistry" face-to-face. Proposals to reform the act were best hammered out around a conference table, he told a newspaper editor. They were not "firebrands to be tossed aloft in a political scramble in the hope of luring a few stray votes." Republicans pressed their advantage. Although Wagner already had the endorsements of the ClO-led American Labor Party and the AFL's state federation, O'Brian renewed his bid for the rank and file with promises to support the AFL's reforms and to oppose the reappointment of Board member Donald Wakefield Smith, thought to be biased in favor of the CIO. ${ }^{113}$

Stimson replied to Wagner with another lengthy letter in the New York Times. Jones \& Laughlin had merely settled the constitutionality of the

111. "Wagner Rejects O'Brian's Bid to Debate Campaign Issues," New York Herald Tribune, October 26, 1938, 1; “Text of Senator Wagner's Reply on New Deal," NYT, October 26, 1938,8 .

112. "Senator Wagner Turns Tail," New York Herald Tribune, October 26, 1938, 22; "Senator Wagner Stands Pat," New York World-Telegram, October 27, 1938, box 6, Wagner Papers; "O'Brian Progress Scares Wagner," Syracuse Post-Standard, October 26, 1938, 4; New York Daily Mirror quoted in Huthmacher, Wagner, 250; "O'Brian Attacks Wagner Job Stand," NYT, October 27, 1938, 4.

113. Wagner to the Editor of the Syracuse Post-Standard, October 29, 1938, box 405, Wagner Papers; "AFL Joins CIO in Supporting Lehman," New York Daily News, October 2, 1938, 2; "A.L.P. Names Lehman with Wild Ovation," New York Daily News, October 4, 1938, 2; "O'Brian Reaffirms Labor Act Stand," NYT, October 31, 1938, 6. 
Wagner Act's procedures, he observed, not whether they were a sensible way to handle a matter "full of class feeling, bias, and counter-bias." The ICC and FTC were inapt comparisons: they protected "all classes of persons" involved in transport or trade. The NLRB was the champion of a single class. Stimson claimed that resentment over "the unfair treatment of litigants under the system now in effect in the Labor Law" had been "one of the main impelling motives" behind the constitutional convention's adoption of the anti-bureaucracy clause. He promised to continue to oppose that ill-conceived measure, but Wagner's intransigence hindered "those of us who are pleading for a fair chance for the development of a proper system among our regulatory commissions." 114

Wagner, of course, did not need Stimson's vote; he could weather some defections by independents; even the New York Times's endorsement of O'Brian on November 1 was surmountable. What alarmed Wagner's camp in the last week of the campaign were reports that "some factions of Labor are not supporting the Senator." 115 A fortnight earlier staffers had joked that O'Brian was "The Man Nobody Knows"; now they endured sleepless nights over the "almost inconceivable" prospect that Wagner might lose..$^{116}$

The defeat in November 1938 of any of several prominent Democrats, including Michigan governor Frank Murphy, "labor's hero of the sit-down strike controversy," would be a blow to the New Deal's prestige, but the loss of as stalwart a congressional ally as Wagner would be a calamity. ${ }^{117}$ Moreover, a victory by O'Brian or by District Attorney Thomas Dewey in his challenge to Governor Lehman would reveal the weakness of the New Deal in Roosevelt's home state, which Democrats would have to carry to retain the presidency in 1940. "For the first time since Franklin D. Roosevelt crushed Herbert Hoover and shattered the Republican organization with the power of his New Deal appeal," the New York Daily News reported, "the political dominance of the President is in peril."118

114. "Text of Stimson Letter on Labor Relations Act," NYT, November 3, 1938, 19.

115. Victor F. Ridder to Robert E. Dowling, October 13, 1938, box 405, Wagner Papers; Maurine Mulliner to Simon H. Rifkind, November 1, 1938, ibid.; O'Brian, "Reminiscences," 447; "Two Senators," NYT, November 1, 1938, 22.

116. Someone in the Wagner camp wrote the title of Bruce Barton's The Man Nobody Knows (1925) across the top of the press release, "Who Is John Lord O'Brian?" Box 407, Wagner Papers. For the sleepless nights of Wagner's associates, see Huthmacher, Wagner, 251. John O'Donnell and Doris Fleeson called Wagner's defeat "almost inconceivable" in "New Deal Control at Stake at the Polls," New York Daily News, November 6, 1938, 8.

117. James Wolfinger, "The Strange Career of Frank Murphy: Conservatives, State-Level Politics, and the End of the New Deal," Historian 65 (2002): 377-402.

118. O'Donnell and Fleeson, "New Deal Control"; NYT, November 6, 1938, 33. "Nation Turns Eyes on State Election," NYT, November 6, 1938, 33. 
On the day Wagner refused to debate O'Brian, Roosevelt announced that he would deliver a radio address on behalf of the state's Democrats on the Friday before the election. Asked at a press conference about his party's chances, Roosevelt affected nonchalance. In fact, he was very concerned. Although he usually kept his distance from the NLRB, Roosevelt had already summoned its members to the White House. ${ }^{119}$

Two recollections of the meeting, both by Chairman Warren Madden and recorded years later, survive. According to Madden, Roosevelt said that Wagner was "somewhat frightened" about his chances and that the senator considered the labor board "his principal handicap for reelection." Roosevelt then asked the Board to amend its rules to permit employers as well as employees to petition for an election. "He did not expand at all on this notion," Madden explained. "Apparently, it was purely political." (It was, in fact, one of the reforms O'Brian had proposed in his first campaign speech and the practice of New York's labor relations board.) Roosevelt seemed to think letting employers call elections "wouldn't hurt," the NLRB chairman recalled, and that "Wagner could use [the change] to give the impression that the board was, after all, reasonable." 120

Madden balked. Employers "really didn't have any rightful interest" in the Board's elections, he protested, because they selected representatives of workers, not their bosses. Besides, employers were sure to petition for an election before unions were ready. "It would be like holding a political election before the campaign," the chairman protested. The "election would be held, the union would be defeated, and that would be the end of the union."121

Roosevelt "purported to see the rightness of that" and asked for a paragraph for his radio address. Madden complied, but when the president spoke from Hyde Park, he barely mentioned the agency. Instead, after confiding that he was glad he had passed up a run for governor in 1918, when he was Dewey's age, Roosevelt turned to the Wagner-O'Brian race. "Just as a Governor is required to be much more than a good prosecutor, so a United States Senator must be much more than a good lawyer." New York's senators had to be leaders in Congress, and no one had worked more effectively "for the benefit of those who need the help and support

119. "Roosevelt will Speak for Ticket at Hyde Park," New York Herald Tribune, October 26, 1938, 8; "Five Million in A.F.L. Want Wagner, Says Green," ibid., November 2, 1938, 12; Diaries and Itineraries, 1933-40, November 2, 1938, President's Personal File, Franklin D. Roosevelt Library, Hyde Park, N.Y.

120. The Reminiscences of J. Warren Madden (1957), 128-29, Oral History Collection, Columbia University, New York, N.Y.; Kim, "Labor Law and Labor Policy in New York State," 217-18. Wagner later endorsed the change as well. "Wagner Favors Only 1 Change in Labor Act," NYT, April 12, 1939, 2.

121. Madden, "Reminiscences," 127-28; Madden, Comell Interview, 39-42. 
of government against oppression and intolerable conditions of living" than Robert F. Wagner. ${ }^{122}$

Roosevelt continued his efforts in the remaining days of the campaign. "The President is fighting harder for Wagner than for any other individual facing the electorate," reported the Daily News on the Sunday before Election Day. "He is making personal phone calls and putting all the great weight of the White House . . into the fight." Both candidates fought to the finish as well. O'Brian explained that his campaign was "based not on political doctrines" but "solely on the power of ideas." He called his public philosophy "reasoned liberalism" and claimed it could reconcile the "increased degree of governmental activity" in Washington with "the maintenance of the individual's freedom and sense of responsibility." Wagner complained that a group "of clever lawyers, including my opponent and also a former member of the Hoover Cabinet"--that is, Stimson-were tempting voters with the plea, "'Of course the Labor Act is constitutional, but it is un-American, and we want a chance to fix it."' He warned his supporters not to "trust your fortunes or your future to the wolves in sheep's clothing who are seeking to trick you into their camp."123

On Election Day O'Brian carried every county above the Bronx save Albany, but a large majority in New York City gave Wagner the victory by some 440,000 votes out of over 4.5 million cast. Dewey, who lost by only 64,000 votes, later told O'Brian that he was sure the Buffalo lawyer would win, because of the "character" of his backers. Although O'Brian cut Wagner's margin of victory by over 40 percent from 1932, he could not persuade enough workers to vote for a Republican. "I couldn't come back into New York politics and in four weeks recover what reputation I'd had years before and at the same time sell myself to a brand new generation," he explained. "It just wasn't in the cards." 124

But did O'Brian succeed in his larger aim, to show the need for reform of federal administrative procedure? O'Brian thought he had. "I feel confident that those views and recommendations we have made will ultimately prevail at Washington," he said after the election. The New York Times praised

122. Madden, "Reminiscences," 128; "Presses New Deal," NYT, November 5, 1938, 1; "Text of President's Address From Hyde Park."

123. O'Donnell and Fleeson, "New Deal Control," 8; "O'Brian Chides New Dealers for Reform Errors," New York Herald Tribune, November 6, 1938, 27; "O'Brian Warns False Liberals Curb Liberties," New York Herald Tribune, November 7, 1938, 4; "Speech of U.S. Senator Robert F. Wagner at American Labor Party Rally, Madison Square Garden," October 31, 1938, box 2, Keyserling Papers; "Speech of U.S. Senator Robert F. Wagner, Morris High School, The Bronx," November 3, 1938, 3, box 2, Keyserling Papers.

124. Manual for the Use of the Legislature of the State of New York, 1933: 912, 1939: 1150-51; O'Brian, "Reminiscences," 447-48; Lehman Plurality Officially 64,004," NYT, December 8, 1938, 5 . 
O'Brian for arguing that "the social program of the Roosevelt Administration can best be achieved if it is undertaken ... with a greater sense of fair play than has marked some recent legislation." "Even in defeat," the newspaper opined, his arguments "ought to affect the conduct of affairs at Washington." An old friend assured O'Brian that his message had "not been lost on the nation," thanks to the "Greek perfection" of "your dignity, your moderation, your clearness." 125

Probably more important in forcing a reassessment of national labor policy than O'Brian's display of classical virtue was Roosevelt's expenditure of so much capital on what ought to have been the easiest of senatorial campaigns, together with the defeats of other New Dealers. A week after the election, with Frank Murphy defeated in his reelection bid and jobhunting in Washington, journalists reported that "a careful stock-taking has gone on in these last few days" among "the New Dealers whose great object is the transformation of the Democratic party into a New Deal or 'progressive' party." The New Dealers recognized "the validity of certain attacks on the W.P.A. and the Labor Relations Board" and agreed that the NLRB's decisions "must cease to have a partisan flavor." Plans had "been laid to increase the assets and write off the liabilities," the journalist confided. Indeed, some moves were "already under way." 126

Donald Wakefield Smith's nomination to the NLRB, pending in Congress on Election Day, was put on hold. In April 1939 Roosevelt withdrew it and named William Leiserson, a labor economist, to straighten out the "mess" at the Board. ${ }^{127}$ "I get too many stories," Leiserson recalled Roosevelt telling him. "If you find what I'm told you're going to find, then I want you to clear those guys out of there." 128 Notwithstanding growing pressure from a congressional investigation, Madden successfully resisted Leiserson's efforts to fire the "left wingers," but by the summer of 1940, "many earnest New Dealers" considered the chairman a political liability and called for his sacking. Roosevelt did nothing until after his election to a third term; then he nominated the labor economist Harry Millis to the chairmanship and gave Madden a face-saving appointment to the U.S. Court of Claims. The staff lawyers who led the NLRB's left wing promptly departed. ${ }^{129}$

125. "O'Brian Wires Wagner," NYT, November 10, 1938, 11; "The Senatorial Election," NYT, November 9, 1938, 22; Gratz to O'Brian.

126. Joseph Alsop and Robert Kintner, "The Capital Parade," Washington Evening Star, November 16, 1938, Al1.

127. "President May Delay Test on Choice of Smith," Washington Post, January 4, 1939, 3; Gross, Reshaping, 89.

128. Leiserson, quoted in Gross, Reshaping, 90-91.

129. "Wagner Act Faces a Crisis," Business Week, July 13, 1940, 24, quoted in Gross, Reshaping, 221; Gross, Reshaping, 226-28. 
Millis and his successor instituted a series of reforms that separated prosecutorial and judicial functions within the NLRB. Meanwhile, the Roosevelt administration blocked legislation to split the labor board into two independent bodies, an "Administrator" who investigated and prosecuted complaints, and a three-member board that heard and passed judgment on them. After the war, however, Congress intervened. First, the Administrative Procedure Act of 1946 strengthened the independence of trial examiners and instituted other procedural reforms for most federal agencies, including the NLRB. Then, in 1947, the Taft-Hartley Act separated the General Counsel from the rest of the NLRB. Nominated by the president and confirmed by the Senate, the General Counsel was charged with investigating and prosecuting unfair labor practices. The Board retained its power to oversee representation elections, but it could act only on cases the General Counsel brought before it. ${ }^{130}$ The formal separation of the "functions of prosecutor and judge and jury" for which O'Brian had campaigned had finally become law. ${ }^{131}$

\section{Lawyers and the End of Reform}

The defeat of the anti-bureaucracy clause and O'Brian's surprising showing suggest that neither reducing bureaucracies to the fact-finding adjuncts of the courts nor freeing administrators to behave in potentially partisan and self-interested ways could claim much electoral support at the end of the 1930s. Business interests, orthodox legalists, regular politicians, and trial lawyers could not win a mandate for institutional Diceyism, nor could New Dealers win a mandate for untrammeled administrative discretion. What could command support was procedural Diceyism. Well before the Administrative Procedure Act of 1946, the judicialization of administrative procedure had emerged as a politically viable way for Americans to have the bureaucracies they wanted and to keep them from being used for partisan or personal purposes. Instead of the hierarchical organization of their European counterparts, American bureaucracies adopted judicialized procedures that gave private parties considerable control over administrative processes, a style of governance dubbed "adversarial legalism" by the political scientist Robert Kagan. ${ }^{132}$

130. Gross, Reshaping, 196-97, 229-31, 264; Harry A. Millis and Emily Clark Brown, From the Wagner Act to Taft-Hartley (Chicago: University of Chicago Press, 1950), 56-58, 63-65.

131. O'Brian, "Reminiscences," 446.

132. Robert A. Kagan, Adversarial Legalism: The American Way of Law (Cambridge, Mass.: Harvard University Press, 2001). 
Procedural Diceyism also served the purposes of two influential and overlapping groups. First, it gave corporation lawyers "administration by administrators"- a stable legal and political environment overseen by knowledgeable officials - but also enough control to keep administrators mindful of the interests of lawyers and their clients. When a prompt and decisive answer served their purposes, the corporation lawyers could dispense with their procedural rights; when it did not, they could demand that due process be scrupulously observed. In thus insisting that agencies mimic the procedures of adversarial, party-driven courts, the corporation lawyers were indeed the advocates of the "moderate state" that Terence Halliday and Lucien Karpik have argued that lawyers tend to be. But by making agencies behave something like courts, they also ensured that their mastery of due process was still a valuable commodity after the rise of the administrative state. Thus, they also illustrated Richard Abel's point that lawyers are most likely to realize the law's "ineradicable potential for liberalism" when and insofar as doing so serves their economic interest. ${ }^{133}$

Procedural Diceyism also appealed to political activists who wanted to shift the nature of competition between the two major parties from the distribution of patronage through networks centered in legislatures to policies implemented through administrative agencies. Judicialized procedures helped ensure that administration was "responsible," that administrators were implementing policy rather than pursuing partisan or personal ends. Even within Democratic administrations procedural Diceyism gained support after the events of 1938. In 1941 the Attorney General's Committee on Administrative Procedure, chaired by Dean Acheson, twice a member of the Roosevelt administration, called for making the officials who presided over administrative hearings more judge-like. In 1942 a similar review commissioned by Governor Lehman concluded that New York's labor relations board should be divided into quasi-executive and quasi-judicial

133. Terence C. Halliday and Lucien Karpik, "Politics Matter: A Comparative Theory of Lawyers in the Matter of Political Liberalism," in Lawyers and the Rise of Western Political Liberalism, ed. Terence C. Halliday and Lucien Karpik (New York: Oxford University Press, 1997), 15-64; Richard L. Abel, "Lawyers for Liberalism: Axiom, Oxymoron, or Accident?" Books-on-Law <http://jurist.law.pitt.edu/lawbooks/revnov98.htm\#Abel> (November 1998). My argument is harder to reconcile with Ronen Shamir's depiction, in Managing Legal Uncertainty, of corporation lawyers as defenders of a court-centered legal "field." Perhaps Shamir and I have focused on different lawyers: litigators, in his case; transactional attorneys, in mine. But perhaps Shamir's theoretical premise, that the corporate bar was part of a court-centered legal field, inclined him to overlook the distinction between institutional and procedural Diceyism. Shamir discussed the ABA's Special Committee on Administrative Law but not the City Bar's counterpart. He mentioned Dulles's attempt to shape the Securities Exchange Act and nullify the Public Utility Holding Company Act but not his opposition to the anti-bureaucracy clause or the Walter-Logan bill. He did not mention Stimson at all. 
components, much as the Taft-Hartley Act would later divide the NLRB. Neither recommendation went uncontested by diehard New Dealers, but the growing support for judicialization among liberals in both parties was unmistakable. ${ }^{134}$

The politics of administrative law in New York in 1938 also has implications for the history of the New Deal. For example, Alan Brinkley has argued that during the early New Deal a wide range of proposals flourished but that after 1937 reformers converged on "a set of liberal ideas essentially reconciled to the existing structure of the economy." "135 The judicialization of administrative procedure may well have contributed to this process. The more credibly lawyers could threaten delay and the imposition of other costs upon agencies, the more likely administrators were to reach an accommodation with private parties. Or consider Sidney Milkis's argument that the New Deal saw the emergence of both "a more national and programmatic party system" and an "administrative apparatus" that ultimately made party government itself "unnecessary."136 The judicialization of administration may well have contributed to both developments. Private parties' insistence on procedural formalities may have kept administrators from straying from their statutory mandates, a prerequisite for "responsible administration." It may also have given private parties leverage over agencies that they could exercise without the help of elected officials. Whether the emergence of procedural Diceyism actually had these effects is a promising topic for future research. ${ }^{137}$

134. Joanna L. Grisinger, "Law in Action: The Attorney General's Committee on Administrative Procedure," Journal of Policy History 20 (2008): 379-418; Dean Acheson, Morning and Noon (Boston, Houghton Mifflin, 1965): 214-15; Harry Shulman to Dean G. Acheson, March 7, 1941, box 3, Acheson Papers; Louis L. Jaffe, "Administrative Procedure Re-Examined: The Benjamin Report," Harvard Law Review 56 (1943): 704-38. I'm grateful to Daniel Sharfstein for drawing my attention to the political significance of Dean Acheson's report and Daniel Gifford for doing the same for Robert Benjamin's.

135. Alan Brinkley, The End of Reform: New Deal Liberalism in Recession and War (New York: Alfred A. Knopf, 1995), 6.

136. Sidney M. Milkis, The President and the Parties: The Transformation of the American Party System since the New Deal (New York: Oxford University Press, 1993), 9.

137. For a recent call for the study of administrative law and practice after World War II, see Reuel E. Schiller, "The Administrative State, Front and Center: Studying Law and Administration in Postwar America," Law and History Review 26 (2008): 415-27. 
$\infty$ 